\title{
Ernst Mach and the Fortunes of Positivism in America
}

\section{Citation}

Holton, Gerald. 1992. Ernst Mach and the Fortunes of Positivism in America. Isis 83 (1): 27-60.

\section{Published Version}

https://www.jstor.org/stable/233992

\section{Permanent link}

http://nrs.harvard.edu/urn-3:HUL.InstRepos:37903228

\section{Terms of Use}

This article was downloaded from Harvard University's DASH repository, and is made available under the terms and conditions applicable to Other Posted Material, as set forth at http:// nrs.harvard.edu/urn-3:HUL.InstRepos:dash.current.terms-of-use\#LAA

\section{Share Your Story}

The Harvard community has made this article openly available.

Please share how this access benefits you. Submit a story.

\section{Accessibility}




\title{
Ernst Mach and the Fortunes of Positivism in America
}

\author{
By Gerald Holton*
}

$\mathrm{B}$ ETWEEN 1910 AND 1914, the Nobel Committee in Stockholm received a number of letters and petitions from scientists nominating Ernst Mach for the Nobel Prize in physics (see Figure 1). Among these, H. A. Lorentz praised Mach's "beautiful works," especially in acoustics and optics, which indeed have not lost their luster to this day; but he added that "all physicists" know Mach's historical and methodological books, and "a large number of physicists honor him as a master and as a guide of their thoughts." (A few years later, in his obituary for Mach in 1916, Albert Einstein said it more strikingly: "I believe even that those who consider themselves as opponents of Mach are hardly aware of how much of Mach's way of thinking they imbibed, so to speak, with their mother's milk.") Ferdinand Braun's nominating letter indicated that while the Nobel Prize might soon have to be awarded for the new theory of space and time, it should first go to Mach, as an early advocate of ideas along the same lines as well as a major experimental physicist; but Braun, too, insisted on Mach's wider influence through philosophical clarifications and "his clear, profound historicalphysical studies." 1

As is well known, only a few years before those letters were sent to Stockholm, Einstein-who later confessed in his Autobiography that Mach's Mechanik had "exercised a profound influence" upon him, and that Mach's example of critical reasoning had been a requirement for his discovering the key to relativity-signed one of his letters to Mach "Your admiring student." 2 Similarly, the next generation of physicists, which struggled with the problems of the new quantum mechanics (e.g., Werner Heisenberg and Wolfgang Pauli), also found in Mach guidance for their thoughts.

At least among scientists, Mach was recognized as one of the most effective fighters in the empiricist challenge to notions implying "absolutes" that had in-

* Jefferson Physical Laboratory, Harvard University, Cambridge, Massachusetts 02138.

I gladly acknowledge support in part by a grant from the Andrew W. Mellon Foundation.

${ }^{1}$ Letters to the Nobel Committee on behalf of Mach from Eduard Suess, Ferdinand Braun, H. A. Lorentz, and Wilhelm Ostwald are printed in John T. Blackmore and Klaus Hentschel, eds., Ernst Mach als Aussenseiter (Vienna: Wilhelm Braunmüller, 1985). The letter of Lorentz (signed with W. H. Julius), 29 Jan. 1912, is on pp. 95-96, quoted on p. 96; Braun's letter, 24 Jan. 1911, is on p. 88. For the obituary see Albert Einstein, "Ernst Mach," Physikalische Zeitschrift, 1916, 17:101-104, on p. 102 .

${ }^{2}$ Albert Einstein, "Autobiographical Notes," in Albert Einstein: Philosopher-Scientist, ed. Paul A. Schilpp (Evanston, Ill.: Library of Living Philosophers, 1949), pp. 2-95, on p. 21; for the letter see Friedrich Herneck, "Die Beziehungen zwischen Einstein und Mach, dokumentarisch dargestellt," Wissenschaftliche Zeitschrift der Friedrich-Schiller-Universität, Jena, Mathematisch-Naturwissenschaftliche Reihe, 1966, 15:1-14, on p. 6. 


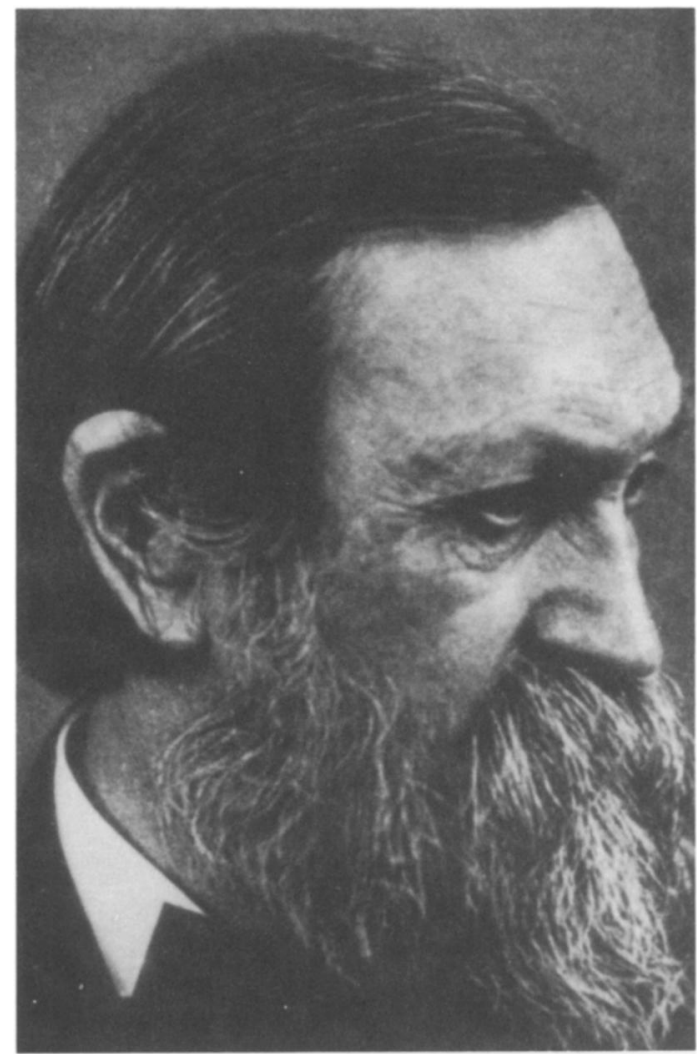

Figure 1. Ernst Mach (1838-1916). (Courtesy of Dibner Library and American Institute of Physics Library.)

fected nineteenth-century science (e.g., absolutes of space, time, substance, vital force). Among philosophers, Mach was admired or attacked for his vigorously held empiricist vision of science, of which perhaps the most essential point was caught in a succinct paragraph by the philosopher Moritz Schlick:

Mach was a physicist, a physiologist, also a psychologist, and his philosophy ... . arose from the wish to find a principal point of view to which he could cling in any research, one which he would not have to change when going from the field of physics to that of physiology or psychology. Such a firm point of view he reached by going back to what is given before all scientific research, namely, the world of sensations. . . . Since all our testimony concerning the so-called external world relies only on sensations, Mach held that we can and must take these sensations and complexes of sensations to be the sole content of those testimonies, and therefore that there is no need to assume in addition an unknown reality hidden behind the sensations. With that, the existence of Dinge an sich is removed as an unjustified and unnecessary assumption. A body, a physical object, is nothing else than a complex, a more or less firm pattern of sensations, i.e., of colors, sounds, sensations of heat, of pressure, etc. ${ }^{3}$

${ }^{3}$ Moritz Schlick, "Ernst Mach," Neue Freie Presse (Vienna), Suppl., 12 June 1926, pp. 10-13, on p. 11. Unless otherwise noted, all translations are mine. 
Mach himself took every opportunity to ensure that his influence would extend far beyond physics, just as he was intent that it would go beyond the borders of his homeland. And indeed it turned out that his teachings lent themselves-more often through the Machian spirit than through direct transmission of raw positivist statements-to adoption or adaptation by many throughout Europe and America who longed for modernism across a great spectrum of intellectual endeavors, and who were infected by the unsuppressible minority view that rejected blatantly metaphysical and hierarchical systems in favor of a unified, empirically based world conception. After Mach assumed his professorship in experimental physics at the University of Prague in 1867 , there developed a far-flung network of admirers and critics of his ideas that, within a few decades, made him one of the seminal figures in the shaping of the modern world view. ${ }^{4}$ His work came to be read, debated, and used not only by physicists but also by major thinkers in mathematics, logic, biology, physiology, psychology, economics, history and philosophy of science, jurisprudence, sociology, anthropology, literature, architecture, and education. ${ }^{5}$

At first slowly and then more and more rapidly, Mach's teachings, often in modified versions, came to be built into the thinking of scholars throughout Europe and, as we shall see, especially in the country that, to his regret, he was never able to visit but had called "the land of my deepest longing," the United States of America. ${ }^{6}$ Indeed, the argument can be made, and will be supported here by exemplary cases, that in the long run there was no more fruitful soil for the development of Mach's ideas than the United States, the country traditionally open to empiricism and pragmatism. The readiness of American scholars in the nineteenth century to be hospitable to some versions of European positivism or empiricism has been discussed, for example, in connection with J. B. Stallo and C. S. Peirce. They did not lack for independent ideas, and they frequently expressed frank disagreements; on that point, one need only follow the original thoughts in Stallo's Concepts and Theories in Modern Physics or read the scathing passages in Peirce's review of Mach's Mechanik. But America was ready for Mach. There is some poetic justice in this. As we know from Mach's various

\footnotetext{
${ }^{4}$ Recently, there seems to have begun another cycle of interest in Mach and his influence, evidenced, e.g., by recent books such as Rudolf Haller and Friedrich Stadler, eds., Ernst Mach-Werk und Wirkung (Vienna: Hölder-Pichler-Tempsky, 1988); Dieter Hoffmann and Hubert Laitko, eds., Ernst Mach: Studien und Dokumente zu Leben und Werk (Berlin: Deutscher Verlag der Wissenschaften, 1991); Blackmore and Hentschel, eds., Ernst Mach als Aussenseiter (cit. n. 1); and Dieter Hoffmann, "Studien zu Leben und Werk von Ernst Mach" (doctoral diss., Humboldt-Universität zu Berlin, 1989) (some of the material in this dissertation has been published in Hoffmann and Laitko, eds., Studien und Dokumente).

${ }^{5}$ E.g., outside science Mach's influence has been documented on Arthur Schnitzler, Hermann Bahr, Richard Beer-Hoffmann, Hugo von Hofmannsthal (who heard Mach lecture at the University of Vienna), and Robert Musil. The effect of Mach's theory of epistemology on visual artists has been described by Joachim Thiele, "Zur Wirkungsgeschichte der Methodenlehre Ernst Machs," in Symposium aus Anlass des 50. Todestages von Ernst Mach, ed. W. F. Merzkirch (Freiburg im Breisgau: Ernst-Mach Institut, 1967), pp. 88-89. We know of the effect of Mach's thoughts on Walter Rathenau, F. von Hayek, Joseph A. Schumpeter, the young Wittgenstein, the young Heinrich Gomperz (later a classical philologist at Vienna), and many medical researchers, including the experimental pathologist Samuel von Basch. See Haller and Stadler, eds., Werk und Wirkung, particularly the essays by Stadler and Peter Mahr, for others among Mach's contemporaries for whom the impact of his ideas can be traced.

${ }^{6}$ In an autobiography of 1910 , cited by John T. Blackmore, Ernst Mach: His Work, Life, and Influence (Berkeley: Univ. California Press, 1972), p. 10.
} 
autobiographies, the Benedictine fathers of his gymnasium thought him to be unteachable and without talent; in turn, the young man felt so oppressed by the regime in Austria-Hungary that he prepared himself to emigrate to America. ${ }^{7}$

To be sure, Mach hardly fitted into the mainstream of Austria-Hungary. He was a freethinker (a fact that later held up his appointment to the professorship in Vienna); politically most nearly identifiable with socialism of the Austrian type; an active fighter against fanatical nationalism and anti-Semitism (the latter even certified by a Prague police report); and a tireless propagandist for "a point of view free from metaphysics, as a product of the general evolution of culture." 8

In the methodology of science, too, Mach at first was an outsider. One of his earliest essays, on a new, instrumentalist basis for defining mass, written in 1866 and already indicating his powerful methodological point of view, was returned as unpublishable by J. C. Poggendorff's Annalen der Physik. It is difficult to realize today how shaky and dogmatic the fundamentals of the physical sciences were prior to the clarifying work in which Mach participated in the last third of the nineteenth century, when some German textbooks in physics still implied that the meaning of concepts was to be sought on a higher, metaphysical plane. What made the difference eventually, in physics but in other fields too, was in good part that philosophically minded young scientists in many countries, in their student years or soon after, and often in reading clubs that they initiated, chanced upon and became fascinated with the writings of Mach and related works. Among these were works by Henri Poincaré, sixteen years younger than Mach, who in direct ways expressed his debt to Mach; and by Pierre Duhem, who wrote to Mach on 10 August 1909: "Permit me to call myself your disciple." 9 Those, together with Hermann von Helmholtz, Gustav R. Kirchhoff, Wilhelm Ostwald, Richard Avenarius, Ernst Haeckel, J. B. Stallo, Karl Pearson, and others of that general cast of mind, were the chief authors of the eagerly read tribal books for guiding thought into the new age.

PAUL CARUS (1852-1919)

Not only scientists and scholars but a variety of interested laymen were attracted to Mach's ideas. In the early phase of the introduction of Mach to America, the crucial and insufficiently recognized intermediary was Paul Carus, editor of the journals the Open Court and the Monist as well as of the parent firm, the Open Court Publishing Company. Born in Germany and with a doctorate from the University of Tübingen, Carus was an amateur philosopher and indefatigable author who sought to develop an agnostic, monistic, and evolutionist world view. He engaged in a massive, mostly unpublished correspondence with Ernst Mach for almost three decades - one of the largest Mach had with anyone-of which

\footnotetext{
${ }^{7}$ E.g., see the autobiographical sketch quoted in Hoffmann and Laitko, eds., Studien und Dokumente (cit. n. 4), p. 431.

${ }^{8}$ Ernst Mach, "Die Leitgedanken meiner naturwissenschaftlichen Erkenntnislehre und ihre Aufnahme durch die Zeitgenossen," Phys. Z., 1910, 9:599-606, on p. 604. For the police report see Blackmore, Ernst Mach (cit. n. 6), p. 83.

${ }^{9}$ Pierre Duhem to Ernst Mach, 10 Aug. 1909, in Blackmore, Ernst Mach, p. 197.
} 
many letters have survived, and through which one can get a sense of Mach's interaction with contemporaries who exhibited interest in his ideas. ${ }^{10}$

Over the years Carus's publishing enterprise, located in the small former prairie town of La Salle, Illinois, saw to it that as many as possible of Mach's works would be made available in English; this included a large number of articles and fifteen books (in original editions, reprintings, etc.). Mach's Popular Scientific Lectures (1895) appeared in English even before the German edition (1896), as did three chapters of Erkenntnis und Irrtum, later gathered by Carus into the little book Space and Geometry. Mach was an enthusiastic collaborator in this constant output by his American publisher, saying in a letter to Carus of 26 August 1890, "It is particularly important for me that the Analysis of Sensations appear in America," and on 20 March 1894, "I lay particular value on writing for the American circle of readers." Similarly, on 11 August 1889 he accepted Carus's proposal that his article in the very first issue of the Monist (1890) (entitled, again in line with a suggestion by Carus, "The Analysis of Sensations-Anti-Metaphysical") would carry the introductory note: "The time seems ripe for the overthrow of all metaphysical philosophies. I contribute this article to your magazine in the confidence that America is the place where the new views will be most developed. E.M."

The hope the men shared, that these publications would attract an ever-widening circle of American readers to Mach's ideas, soon began to be fulfilled; and even though the most prominent scholars among them could of course read Mach's works in the original German editions, they tended to cite these English translations. As Mach noted with satisfaction, his Mechanik had a much larger distribution in the English version brought out by Carus than in the original German one. ${ }^{11}$

Many of the bare facts in the relation between Carus and Mach have been known for some time. ${ }^{12}$ What has been missing, but is needed to understand how Carus in this then-unlikely outpost could become Mach's first missionary in the United States, is a more detailed, sympathetic understanding of what these two men meant to each other, as well as a sense of how the collaboration of this odd pair amounted to an act of inspired symbiosis. Such a treatment will have to be given elsewhere; suffice it to note here that Carus had read Mach's Mechanik with greatest interest when it appeared in 1883 and later wrote, "I at once recog-

${ }^{10}$ One hundred thirty-six letters from the Open Court Publishing Company records of 1886-1930 were deposited by the Edward C. Hegeler Foundation and members of the Carus family in December 1968 at Southern Illinois University at Carbondale, Illinois; these can be found in the Morris Library Special Collections-Manuscripts. They include correspondence with Ludwig Mach. These holdings overlap with those at the Ernst-Mach-Institut at Freiburg im Breisgau.

I am grateful to the Curator of Manuscripts at the Morris Library, Sheila Ryan, for making copies of the correspondence with Ernst and Ludwig Mach available to me and for permission to quote excerpts from the correspondence. I also thank Blouke Carus, Paul Carus's grandson and president of the Open Court Publishing Company, for historical information.

${ }^{11}$ Ernst Mach to Paul Carus, 22 Apr. 1895; all correspondence between Mach and Carus or other representatives of Open Court is in the Morris Library Special Collections cited in n. 10.

${ }_{12}$ See, e.g., relevant passages in Ralph E. McCoy, ed., Open Court: A Centennial Bibliography, 1887-1987 (La Salle, Ill.: Open Court, 1987), especially the "Historical Introduction" by Sherwood J. B. Sugden. To Sugden's bibliography on Carus and Open Court (p. 27), I would add Joachim Thiele, "Paul Carus und Ernst Mach," Isis, 1971, 62:208-219; and Thiele, Wissenschaftliche Kommunikation: Die Korrespondenz Ernst Machs (Kastellaun: A. Henn Verlag, 1978). 
nized in him a kindred spirit." Indeed, the English translation of the Mechanik was one of the first projects of the fledgling company, Mach assuring Carus, "I will be very glad to work over the English text."13 Moreover, during Mach's lifetime, apart from two early pieces in the Philosophical Magazine (London; 1865, 1866), all twenty articles of Mach that appeared in English, whether translated from published works or from manuscripts, appeared in the Open Court or the Monist. The parent company was also responsible for all of his books in English translation.

Carus clearly revered Mach, even if he occasionally, in letters, editorials, and articles, expressed reservations on specific points. He saw himself as a fellow intellectual whose "admiration for Professor Mach cannot be less than that of his most ardent disciple and follower." In return, Mach's letters demonstrated his pleasure and respect. For example, he wrote to Carus on 26 January 1890 that he was delighted with Carus's new book Fundamental Problems and added, "Your motto . . . 'positive science' is one with which I am in full agreement. In general, your monistic conception is very sympathetic to me, and I find many points of contact there with my own considerations." 14

One would expect Mach to reach out to Carus in this way. He was not one to leave any opportunity for increasing his influence to chance. But there can be little doubt that the sentiment behind Mach's published and private expressions of gratitude to Carus was genuine. And of course he had uncommonly good reason to feel that way. The labors of Carus's firm were putting him in touch with "the American public" and made his work "become international." ${ }^{15}$ Carus made at least two pilgrimages to Mach $(1893,1907)$ and planned at least one additional visit (1913). Mach may also have perceived the La Salle operation in the context of his long-standing sympathy for America. Like so many Europeans, he may have had a somewhat romantic attitude on this score; thus, among the books on America that Carus undertook to send him from time to time, there were some on American Indians, in whom he was also interested through anthropological studies. Then, too, the New World continued to beckon for the Mach family. On various occasions his son Ludwig planned to emigrate there; Mach himself continued to hope for at least a visit, although nothing came of it. And Mach had not only admirers in the United States, but also at least one family member, a cousin-William Lang-in Chicago. ${ }^{16}$

In short, Mach's appearance on the American scene was so massive and successful in good part because of the multiple bonds between Mach and Carus. In

${ }^{13}$ P. Carus, "Professor Mach's Philosophy," Monist, 1906, 16:331-356, on p. 332; and Mach to Carus, 14 Apr. 1889. The work was difficult and slow, and the translation by Thomas J. McCormack (from the 2nd German ed.) appeared in 1893; but on 15 Feb. 1894 McCormack could assure Mach, "We have had some excellent reviews of the Science of Mechanics."

${ }^{14}$ Paul Carus, "Criticisms and Discussions," Monist, 16:629. Mach's ideas, however, were not all that transparent to his commentators, and they also changed over time; thus in a letter to Carus, 7 June 1912, he expressed his doubts about monism as long as it had so many different meanings to different adherents.

${ }^{15}$ Mach to Carus, 7 Jan. 1895; and Ludwig Mach to Carus, 28 Feb. 1913.

16 As Carus wrote Mach on 10 Nov. 1911, he and Edward Carl Hegeler (founder of the publishing company) had hoped early on to bring Ludwig to La Salle, to "see what he could do with American industrial work." On 27 Sept. 1889 Carus had written to Mach that it was a pity he could not accept the invitation of "Clark University in Wooster [sic], Massachusetts." On William Lang see Mach to Carus, 4 Sept. 1892. 
addition to their personal friendship, they perceived each other to be kindred spirits indeed, as well as beleaguered fellow-Aussenseiter who were fighting for a common vision of the modern scientific world conception, while all around them, as Mach put it, "This is the time of anti-modernism." 17

\section{WILLIAM JAMES (1842-1910)}

The first major American scientist on whom Mach's work had some documentable direct influences-and who did not have to wait for the English translations-was William James, only a few years younger than Mach, and by education and interests well matched: he had originally trained in physical science and medicine; had traveled widely in Europe, including a brief but important period as a student in Berlin, Heidelberg, and Dresden; and had served as instructor of anatomy and physiology and, finally, as professor both of philosophy and of psychology at Harvard University. His profound and influential Principles of Psychology (1890) and Pragmatism (1907) established his reputation as one of the seminal thinkers of his day in America, one of the few American philosophers read widely in Europe.

His philosophy of pragmatism, developed in the first instance as a way out of a personal struggle that has been called James's "Kant crisis," overlapped with Machian positions in many ways, for example, in finding the meaning of ideas in the sensations that may be expected from their realization. As early as 1875 he was reacting against the previous generation of what he called "the Heavenscaling Titans" of Germany, against whom he named Gustav Theodor Fechner, Helmholtz, and Mach among models of the new breed whose "detachment of mind is very healthy" from either "theologic or anti-theologic bias." James was also impressed by Mach's experimental results, to which he referred in many places in his writings; in addition, as Ralph B. Perry noted, "From Mach, James had learned something of what he knew about the history of science, and he had readily accepted his view of the biological [evolutionary] and economic function of scientific concepts." 18

James himself put his relation with Mach most perceptively when he wrote on 27 June 1902, in response to Mach's request that he accept the dedication of the new, third edition of Populär-wissenschaftliche Vorlesungen:

I suppose that sympathies are usually reciprocal, and that just as I have taken such delight in the whole tone and temper of your thoughts, so you have found something in the tone of my writings, imperfect though they are, which has pleased you. . . . I trust ... that you and I may yet read many further productions by each other and contribute jointly to the establishment of the truly philosophical way of thinkingwhich I believe to be, on the whole, our way! ${ }^{19}$

${ }^{17}$ Mach to Carus, 25 Dec. 1910.

${ }^{18}$ Judith Ryan, "American Pragmatism, Viennese Psychology," Raritan, 1989, 8:45-55, on p. 48; William James, Essays, Comments, and Reviews (Cambridge, Mass.: Harvard Univ. Press, 1987), p. 297; and Ralph Barton Perry, The Thought and Character of William James (Boston: Little, Brown, 1936), p. 463.

19 William James to Mach, 27 June 1902, in Thiele, Wissenschaftliche Kommunikation (cit. n. 12), p. 172. 
A few months later, having received Mach's new book with the dedication in "Sympathie und Hochachtung," James wrote on 19 November 1902 of his attempt to give his students at Harvard "a description of the construction of the world built up of 'pure experiences' related to each other in various ways, which are also definite experiences in their turn."

In using the word sympathy, both men pointed to the heart of the troublesome concept "influence." It is not enough to find passages in which one person echoes another. What counts far more is the development of a state of elective-but also selective-affinity, as was the case for Mach and James. ${ }^{20}$

It is of course no accident that psychology was the first scientific field to feel Mach's impact. His own researches in experimental psychology and psychophysics during much of his life made it likely that this part of his work would be read attentively among psychologists in America. ${ }^{21}$ They were also open to his ideas in and beyond psychology because of the native empiricist tradition in the United States in psychology and philosophy, fields that at that time were not yet clearly disaggregated. To preview a subsequent development, we may note that even in 1930, when Moritz Schlick returned to Vienna from a missionizing visit to the United States and gave at the newly founded Ernst-Mach-Verein a report entitled "The Scientific World Conception of the United States," he singled out one field above all others, saying, "The great respect for empirical psychology provides a favorable ground for the scientific world conception" there. And Herbert Feigl, one of Schlick's favorite students, having gone to America in 1930 as "the first 'propagandist' of our outlook," returned to Vienna with the news that he considered the behaviorist psychologists in the United States to be among "the closest allies our movement acquired in the United States."22

That alliance noted in the 1930 s had been prepared, as it were, in part by the contacts between James and Mach, starting in the $1870 \mathrm{~s}^{23}$ In 1882 , when both James and Mach were still only at the threshold of becoming widely known,

20 James to Mach, 19 Nov. 1902, ibid., pp. 173-174. Among evidences of selective disagreements see, e.g., several of Mach's letters to Anton Thomsen, in Blackmore and Hentschel, eds., Ernst Mach als Aussenseiter (cit. n. 1), pp. 86, 92, 111-113, in which he distances himself from aspects of James's publications; for James's own reservations see, e.g., William James, Pragmatism (Cambridge, Mass.: Harvard Univ. Press, 1975), p. 34, where Mach is listed among authors who show that "human arbitrariness has driven divine necessity from scientific logic."

${ }^{21}$ Various direct and indirect debts to Mach on the part of psychologists ranging from Edward B. Titchener to E. G. Boring have been noted; see, e.g., Blackmore, Ernst Mach (cit. n. 6); and Laurence D. Smith, Behaviorism and Logical Positivism: A Reassessment of the Alliance (Stanford, Calif.: Stanford Univ. Press, 1986). One should certainly add here the psychophysicist S. S. Stevens.

${ }^{22}$ Report on Schlick's talk, in Erkenntnis, 1930, 1:75-76. Schlick added significantly: "One may regard John Dewey of Columbia University, New York, as a typical representative of American thought [in philosophy]. His philosophy . . . moves on the whole quite in the paths of empiricism in which Ernst Mach was a leader." Herbert Feigl, "The Wiener Kreis in America," in The Intellectual Migration, ed. Donald Fleming and Bernard Bailyn (Cambridge, Mass.: Harvard Univ. Press, 1969), pp. 630-673, on pp. 630, 661 .

${ }^{23}$ No letters from that decade have survived. But James had begun to express his admiration of Mach's work in print before they met; e.g., in 1880 he discussed Mach's "wonderfully original little work, 'Beiträge zur Analyse der Empfindungen' ": quoted in William James, Principles of Psychology (New York: Henry Holt, 1890), Vol. 2, p. 50.

For the correspondence between Mach and James see Henry James, Jr., ed., The Letters of William James (Boston: Atlantic Monthly Press, 1920); and J. Thiele, "William James und Ernst Mach: Briefe aus den Jahren 1884-1905," Philosophia Naturalis, 1966, 9:298-310, or its essentially identical reprinting in Thiele, Wissenschaftliche Kommunikation (cit. n. 12), pp. 168-176. 
James came to Prague during one of his European study tours and wrote to ask Mach for an interview, noting that he, James, was "very familiar" with his writings. Mach (whose English was quite good) had also read some of James's studies, and the two had a glorious meeting in Prague on 2 November 1882, in which James was overwhelmed by Mach's intellectual power. ${ }^{24}$ There followed years of interactions through citations of each other's publications as well as in their correspondence. ${ }^{25}$ The originals of six of Mach's letters to James are at the Houghton Library at Harvard. On 29 January 1884 Mach announces to James that the latter's "schönen Versuche" will be taken into account in his new book; on 17 October 1890 he calls the just-received copy of Principles of Psychology "very beautiful and interesting." On 10 June 1902 he thanks James for "so viele an Belehrung und Genuss reiche Stunden." In his well-known letter of 28 June 1907, Mach confirms that in his way of thinking he stands close to pragmatism, although without ever having used that term. And on 6 May 1909 he acknowledges that to James's books, of which he had now a substantial number, "verdanke Ich eine Menge neuer Gesichtspunkte."26

In addition to the citations and quotations in their publications and the indications in the correspondence, a third essentially instrumentalist evidence of interaction exists in the form of annotations in published works. William James's extensive collection of books was partly dispersed after his death, but a large number were preserved in Houghton Library at Harvard. In many of these books he had entered annotations in the form of marginalia, underlinings, queries, summaries, and so forth. The authors range from Descartes to Stallo and Bernard Brentano. ${ }^{27}$

It is clear from references in James's publications that he had access to earlier editions and copies other than those that have survived; but an indication of the care with which he read Mach's works can be seen from James's annotations of his extant copies of Erkenntnis and Analyse. A quick scanning of the first yields

\footnotetext{
${ }^{24}$ William James wrote to his wife on 2 Nov. 1882 that he had listened to Mach lecture on mechanics and found it "the most artistic lecture I ever heard." Their subsequent four-hour talk was "an unforgettable conversation. I don't think anyone ever gave me so strong an impression of pure intellectual genius. He apparently has read everything and thought about everything, and has an absolute simplicity of manner": in Thiele, Wissenschaftliche Kommunikation, p. 169. Similarly, after reading Ostwald's Vorlesungen über Naturphilosophie, James wrote to Hugo Münsterberg (23 July 1902), "I don't think I ever envied a man's mind so much as I have envied Ostwald's-unless it were Mach's": Ralph Barton Perry, The Thought and Character of William James, 2 vols. (Boston: Little, Brown, 1935), Vol. 2, p. 288.

${ }^{25}$ E.g., Mach refers to James in fourteen places in Analysis of Sensations, often with laudatory comments, mostly concerning experimental results. For his part, James refers nine times to Mach in Principles of Psychology, again usually to experimental results, and in some cases at considerable length. Mach also appears in James's lecture notes for five philosophy courses, given at Harvard College over a period from 1879 to 1905; cf. William James, Manuscript Lectures (Cambridge, Mass.: Harvard Univ. Press, 1988).

${ }^{26}$ These letters from Mach to James are in William James Letters, Houghton Library, Harvard University, Cambridge, Massachusetts. They are printed in Thiele, Wissenschaftliche Kommunikation (cit. n. 12), pp. 168-176.

${ }^{27}$ See the editorial comment in William James, Some Problems of Philosophy (Cambridge, Mass.: Harvard Univ. Press, 1979), notes starting on p. 121. Mach's books surviving in that collection are Grundlinien der Lehre von den Bewegungsempfindungen (Leipzig: Wilhelm Engelmann, 1875), Die Mechanik (Leipzig: F. A. Brockhaus, 1883), Analyse der Empfindungen, 4th ed. (Jena: Gustav Fischer, 1909), Populär-wissenschaftliche Vorlesungen (Leipzig: Barth, 1903), and Erkenntnis und Irrtum (Leipzig: Barth, 1905).
} 
thirty-two underlinings (including sentences and parts of paragraphs) and thirteen marginal comments (ranging from "W. J.," to indicate a similarity with his own views, to substantial comments indicating agreement or disagreement) ${ }^{28}$

Similarly, in James's copy of Analyse there are thirteen underlinings or other markings in the first thirty-eight pages, and more than two dozen annotations. Moreover, in both books James made indexes of his own inside the back covers, with special references to those passages that showed similarities with his position or current interest. Reading these markings, annotations, and indexes gives substance to James's comment, in his letter to Mach acknowledging receipt of Erkenntnis, that he will "devour it greedily." As Judith Ryan has shown, in the case of Mach's Analyse "James was clearly combing [this book] for pragmatic leanings that might confirm his own belief in the value of everyday reasoning." Examination of James's copy also supports her argument that Mach's treatise, in the 1886 edition, was the "hidden link between James' 1884 essay ["The Stream of Thought"] and the 1890 chapter in his Principles of Psychology."29

In terms of James's earlier intellectual formation, even more significant may be the annotations in his copy (also preserved at Houghton Library) of Mach's Mechanik in the original edition of 1883, for which James again prepared his own supplementary index of important ideas. This is the book that starts with the famous challenge: "This work is not a text to drill the theorems of mechanics. Rather, its intention is one of enlightenment-or, to put it still more plainly, an anti-metaphysical one." Hence it is by no means easy to grasp-being simultaneously a study in the history of science, a detailed analysis of topics in mechanics, a tract on how to make one's ideas clear, and a sequel to certain eighteenthcentury Enlightenment treatises. But James's copy shows that he mastered it; judging by his annotations, he appears to have been most interested in Mach's discussion of Newton's views on time, space, and causality, and in what James's index calls the "empirical character" of concepts such as that of equilibrium, for which James searched the work carefully, finding entries for twelve pages.

Other authors have treated aspects of the correspondence between Mach and James, their agreements and occasional disagreements. ${ }^{30}$ But James's copies of Mach's book graphically demonstrate the intense impression they made on him during the period in which he was engaged in writing his own major works.

\section{JACQUES LOEB (1859-1924)}

After the death of William James in 1910, American thinking in psychology was perhaps most influenced by John B. Watson, who may be considered to have

\footnotetext{
${ }^{28}$ Attention has been drawn to three of the marginalia in the introduction by Erwin N. Hiebert to the reprinting of Ernst Mach's Knowledge and Error (Boston: Reidel, 1976).

29 James to Mach, 9 Aug. 1905, in Thiele, Wissenschaftliche Kommunikation (cit. n. 12), p. 175; and Ryan, "American Pragmatism" (cit. n. 18), pp. 52-53.

${ }^{30}$ E.g., Blackmore, Ernst Mach (cit. n. 6); Hiebert, introduction to Knowledge and Error (cit. n. 28); Perry, Thought and Character of William James (cit. n. 24), Vol. 2; Ryan, "American Pragmatism"; Susan Haack, "Pragmatism and Ontology: Peirce and James," Revue Internationale de Philosophie, 1977, 31:377-400; Peter T. Manicas, "Pragmatic Philosophy of Science and the Charge of Scientism," Transactions of the Charles S. Peirce Society, 1988, 24:179-222; Gerald E. Myers, William James: His Life and Thought (New Haven, Conn.: Yale Univ. Press, 1986); and Hilary Putnam and Ruth Anna Putnam, "William James's Ideas," Raritan, 1989, 8:27-44.
} 
launched the school of behaviorism with his article "Psychology as the Behaviorist Sees It" (1913). This school soon encompassed three of the behavioral (or, more properly, neobehavioral) psychologists who in their respective work periods were arguably the most predominant experimental psychologists in the United States: Edward C. Tolman, Clark L. Hull, and B. F. Skinner. ${ }^{31}$ Like Watson himself, each had a large, acknowledged debt to the Machian philosophy of science. But the lines of descent from Ernst Mach to these are so variegated, and the strands in the growing network of intellectual alliances, oppositions, and personal relationships are multiplying so rapidly as we come to the more recent period, that we must make a brief detour to mention one of Watson's important teachers in the United States, the almost fanatical physicalist interpreter of animal behavior Jacques Loeb.

Loeb was born in the Rhineland in 1859 , educated at Strassburg and elsewhere in one of the main traditions of German physiology of the time, came to the United States in 1891, taught at various universities, and finally joined the Rockefeller Institute in New York in 1910. His best-known work, in the period roughly from 1890 to 1915, was on artificial parthenogenesis and tropism; his most powerful book, whose message was clear in its very title, was The Mechanistic Conception of Life, expanded from an invited address given in 1906 at the first congress of the International Monist League. ${ }^{32}$

In 1887 Loeb had been troubled by fundamental questions both in biology and about his duties as a scientist. To clarify his thoughts, he initiated a correspondence with Ernst Mach at Prague. He wrote to Mach: "Your Analysis of Sensations and your History of Mechanics are the sources from which I draw the inspiration and energy to work," and he cited particularly the first chapter of the former book, which is entitled simply "Antimetaphysical," as expressing ideas Loeb acknowledged to be "scientifically and ethically the base on which I stand, and on which, in my opinion, the scientist must stand." 33

As was his habit, Mach generously responded to and nurtured a promising link of discipleship. The correspondence continued for over a decade, with Loeb calling Mach "a mentor" and "my teacher." Loeb's initial scientific program was essentially derived from Mach (and in part from Mach's closest friend, the engineer and social reformer Joseph Popper-Lynkeus). This included acceptance of "Mach's attack on 'metaphysical' tendencies in science, his faith in the ethical values inherent in research, and his belief in the fundamental unity of science and technology." 34

Loeb's adherence to such ideals is also evidenced by his associating himself, as one of its thirty-two signers, with a strange and revealing document. It is the public manifesto, issued sometime between late 1911 and summer 1912 on behalf of a newly emerging Gesellschaft für positivistische Philosophie, under the title

\footnotetext{
${ }^{31}$ All three have been studied most recently in depth by Laurence D. Smith in Behaviorism and Logical Positivism (cit. n. 21), on which I shall rely to some extent.

${ }^{32}$ For a good account of Loeb's life and work see Philip J. Pauly, Jacques Loeb and the Engineering Ideal in Biology (New York: Oxford Univ. Press, 1987). An excellent, concise introduction to Loeb's thought has been provided by Donald Fleming in his introduction to the reprint edition of Loeb's Mechanistic Conception of Life (Cambridge, Mass.: Harvard Univ. Press, 1964), pp. vii-xli.

${ }_{33}^{33}$ Pauly, Loeb and the Engineering Ideal, p. 42.

${ }^{34}$ Ibid., p. 5.
} 


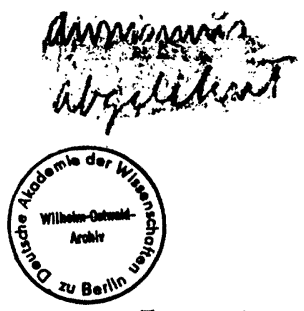

\section{Alufruf!}

Eine umfassende Weltanschauung auf Grund des Tatsachenstoffes vorzubereiten, den die Einzelwissenschaften aufgehäuft haben, und die Ansătze dazu zunăchst unter den Forschern selbst zu verbreiten, ist ein immer dringenderes Bedürínis vor allem für die Wissenschaft geworden, dann aber auch für unsere Zeit überhaupt, die dadurch erst erwerben wird, was wir besitzen.

Doch nur durch gemeinsame Arbeit vieler kann das erreicht werden. Darum rufen wir alle philosophisch interessierten Forscher, auf welchen wissenschaftlichen Gebieten sie auch betätigt sein mögen, und alle Philosophen im engeren Sinne, die zu haltbaren Lehren nur durch eindring zndes Studium der Tatsachen der Erfahrung selbst zu gelangen hoffen, zum Beitritt zu einer Gesellschaft für positivistische Philosophie auf. Sie soll den Zweck haben, alle Wissenschaften untereinander in lebendige Verbindung zu setzen, überall die vereinheitlichenden Begriffe zu entwickeln und so zu einer widerspruchsfr zien Gesamtauffassung vorzudringen.

Um nähere Auskunit wende man sich an den mitunterzeichneten Herrn Dozent M. H. Baege, Friedrichshagen b. Berlin. Waldowstraße 23.

E. Dieggen,
Fabrikbesitzer u. philos. Schriftste
Bensheim.
Prof. Dr. Föppl,
München.
Prof. Dr. Flibert,
Geh. Rog,-Rat. Gottingen.
Prof. Dr. Kammerer,
Geh. Reg.-Rat, Charlottenburg.
Prof. Dr. Camprecht,
Geh. Holrat, Leipzlg.
Prof. Dr. E. mach,
Hofrat. Wien.
Josef Popper,
Ingenteur, Wien.
Prof. Dr. Ribbert,
Geh. Medizlnalrat, Bonn.

Prof. Dr. Schuppe,

Geh. Reg.-Rat. Breslau.

Prof. Dr. Verworn, Bonn.

\section{Prot. Dr. Einstein, Pras.}

Prot. Dr. S. Jreud,

Prot. Dr. Jensen, Göttingen.

Prot. Dr. B. Kern,

Obergeneralarzt u. Inspekteur der II. Senittats-Inspektion, Berlin.

Prof. Dr. v. Ciszt,

Geh. Justizrat. Berlin.

Prot. Dr. 6. E. Mullier,

Geh. Reg.,-Rat. Gobttingen.

Prot. Dr. Potonié,

Konnigl. Landesseologe, Berlin.

Prot. Dr. Roux,

Geh. Medizinalrat, Halle a. S

Prof. Dr. Ritter v. Seeliger, München.

Prof. Dr. Wermieke,

Oberrealschuldirektor u.

Privat-Dozent, Braunschweig.

Pror. br. Th. Zienen.

Geh. Medizinalrat. Wiesbaden.

\section{Prof. Dr. Forel Yvorne.}

Prof. Dr. Beim, Geh. Hoirat, Dresden. Prot. Dr. Jerusalem, Wien.

Prot. Dr. F. Klein,

Geh. Reg.-Rat, Gơttıngen.

Pror. Dr. Loeb, Rockefeller-Institute. New-York,

Dr. maller-Lyer. München.

Pror. Dr. Rhumbler, Hann.-Münden.

Prof. Dr. J. E. S. Schiller, Corpus Christl College. Prot. Dr. Cönnies,

Prot. Dr. Wiener, Geh. Hoirat, Lelpzig.
I. ந. Baege,

Dozent d. Frelen Hochschule Berlin
Prof. Dr. Pezoldt,

Oberlehrer u. Priv.-Dozent.

Figure 2. Appeal for the formation of the Gesellschaft für positivistische Philosophie. (Courtesy of Wilhelm-Ostwald-Archiv, Deutsche Akademie der Wissenschaften zu Berlin.)

printed in bold, large type: "Aufruf!" 35 The document (Figure 2) deserves more attention than it has received, not least because it is in some respect a striking preview of the core tenets of another, more famous group publication, the seminal manifesto of the Vienna Circle that would be issued in 1929.

35 The main text was reprinted, although with an incomplete list of signers, in Physikalische Zeitschrift, 1912, 13:735. Among its rare mention in secondary sources is a reference to its existence in Friedrich Herneck, "Albert Einstein und der philosophische Materialismus," Forschung und Fortschritte, 1958, 32:204-208, on p. 206. I thank the Deutsche Akademie der Wissenschaften zu Berlin for a copy of the original manifesto, from its Wilhelm-Ostwald-Archiv. 
The text of the Aufruf runs as follows (in my translation):

\section{Appeal!}

To bring forth a comprehensive Weltanschauung, based on the factual material that has been accumulated by the separate sciences, is an ever more urgent need; this is true first of all for science [Wissenschaft] itself, but also for our era as such, which will only thereby have earned what we now own.

But this aim can be achieved only through the common labors of many. Therefore we call upon all philosophically interested researchers-no matter in which scientific fields they may be active-and upon all philosophers in the narrow sense of the term whose expectation is to reach by themselves valid knowledge only through the penetrating study of the facts of experience, to join a Society for Positivistic Philosophy. The Society shall have the purpose of establishing lively connections among all the sciences, of developing everywhere the unifying ideas [vereinheitlichende Begriffe], and thus press forward toward a contradiction-free unitary conception [Gesamtauffassung].

The task of launching this appeal had been put in the hands of two men. One was Mach's most beloved acolyte, the Spandau schoolteacher Joseph Petzoldt, who soon resurfaced as editor of the newly founded Zeitschrift für positivistische Philosophie (issued as "Organ der Gesellschaft für positivistische Philosophie") and the author of its first article, an elaboration of the call to arms under the title "Positivistische Philosophie" that pointed to Mach and Kirchhoff as incarnations of the old ideal. The other man was M. H. Baege, docent in Berlin, who would soon be referred to in the Zeitschrift as its publisher. ${ }^{36}$

The long list of signatories of the Aufruf formed an impressive, widely dispersed group of individuals who, despite individual differences, felt they could agree on these central beliefs. They included, in addition to Mach himself, such figures as Albert Einstein (Prague), August Föppl (Munich), Sigmund Freud (Vienna), Georg Helm (Dresden), David Hilbert (Göttingen), Wilhelm Jerusalem (Vienna), Felix Klein (Göttingen), Joseph Popper[-Lynkeus] (Vienna), F. C. S. Schiller (Oxford), and Ferdinand Tönnies (Kiel). It was this emerging Denkkollektive that "Prof. Dr. Loeb" of New York chose to join as a fellow signer. ${ }^{37}$

\section{B. F. SKINNER (1904-1990)}

The detailed connections between Mach and Loeb, and between them and the later behaviorists in the United States, are inviting research topics. But we can

${ }^{36}$ Headquartered in Berlin, both the Gesellschaft and the Zeitschrift, led by Petzoldt, lasted until 1915; the former was revived in 1927 as the Internationale Gesellschaft für empirische Philosophie, of which Petzoldt and Hans Reichenbach were members. Cf. Blackmore and Hentschel, eds., Ernst Mach als Aussenseiter (cit. n. 1), p. 107.

${ }^{37}$ A related document, "Gründe für die Bildung einer Gesellschaft für positivistische Philosophie," was reprinted in Isis, 1913, 1:107-110, and in the Journal of Philosophy, Psychology, and Scientific Methods, 1912, 9:419-420.

A striking omission in both documents is that of Ostwald. The copy in his archives has his annotation, "abgelehnt." An indication of how this affected Mach and Petzoldt, and how deeply they were involved in the Aufruf, emerges from a paragraph in one of Petzoldt's letters to Mach, dated 9 Jan. 1912. There he lauds Mach for having refused Ostwald's invitation to be honorary president of the Monistenbund, and indicates that this was fair revenge: "Ostwald should now regret that he did not sign our Aufruf." The letter is quoted in Blackmore and Hentschel, eds., Ernst Mach als Aussenseiter, p. 100. For evidence that additional adherents to the Aufruf were expected, including Enriques, Poincaré, and Duhem, see Revue Philosophique, 1913, 76:558-559; and Klaus Hentschel, Die Korrespondenz Petzold-Reichenbach (Berlin: Sigma, 1990), pp. 16-24. 
focus here only on the propagation of Mach's effect in the formation of one major psychologist of the recent period, Burrhus F. Skinner. Born in 1904, he was to his death in 1990 undoubtedly the most direct and self-confessed disciple of Ernst Mach among native-born American scientists in this century. As he stated in his autobiography, The Shaping of a Behaviorist, he recalled only two science books he had read as an undergraduate: Loeb's Comparative Physiology of the Brain and Comparative Psychology and The Organism as a Whole, with their largely positivistic approach to the study of the behavior of animals. When Skinner came to Harvard University to do his graduate work in 1928, his thesis supervisor, in whose laboratory he remained for five years, was the physiologist W. J. Crozier. It is not accidental that Crozier's own teacher had been Jacques Loeb. Indeed, "it was this ultra-positivistic form of Loebian biology that Skinner encountered at Harvard." 38

But before Skinner was ready to choose either his research topic or Crozier's laboratory, while still in his preparatory courses at Harvard, another push in the same direction came while he was taking a course on the history of science given by George Sarton-who regarded himself as a Duhemian positivist-and the physiologist Lawrence J. Henderson. There Skinner was assigned the reading of Mach's Mechanics. It had a permanent effect on him. In an interview on 8 June 1988 Skinner stated to me categorically: "I was totally influenced by Mach via George Sarton's course, and quickly bought Mach's books, Science of Mechanics and Knowledge and Error. My Ph.D. thesis was published ${ }^{39}$ as 'The Concept of the Reflex in the Description of Behavior.' "In that interview he delighted in adding that a fellow graduate student in Crozier's laboratory had been Gregory Pincus, the experimental biologist who went on to develop the so-called birth control pill. Thereby, Skinner said, under Crozier's direction "Pincus worked on the control of biology, whereas I worked on the control of behavior." In reading Mach, Skinner was particularly struck by the idea that scientific concepts have adhering to them often obscurantist traces of their earlier versions; the task of current practitioners, both believed, was to release them from the grasp of "metaphysical obscurities," as Mach had put it.

In writing his doctoral thesis, the young Skinner saw a way of applying the Machian point of view to the clarification of such concepts as the "reflex" of intact organisms, something he considered to be as basic in psychology as, say, mass is in physics. As Skinner recollected, he was "following a strictly Machian line, in which behavior was analyzed as a subject matter in its own right as a function of environmental variables without reference to either mind or the nervous system." That was "the line that Jacques Loeb ... had taken." 40 In this radically empiricist mode, the study of behavior reduced itself for Skinner, to start with, to the observation of the motion of the foot of a food-deprived rat, pressing down a small lever in an experimental box of standard size. Explanation

${ }^{38}$ B. F. Skinner, The Shaping of a Behaviorist (New York: Knopf, 1979); and Smith, Behaviorism and Logical Positivism (cit. n. 21), p. 277.

${ }^{39}$ B. F. Skinner, "The Concept of the Reflex in the Description of Behavior," Journal of General Psychology, Oct. 1931, 5, no. 4: 427-457.

${ }_{40}$ B. F. Skinner, review of Smith's Behaviorism and Logical Positivism, in Journal of the History of the Behavioral Sciences, 1987, 23:204-209, on p. 209 (emphasis in original). 
was reduced to description, causation to the notion of function, and the chief goal was the correlation between observed events.

Skinner's doctoral thesis is still in the Harvard Archives (and differs in some details from the portions that were later published). There, Skinner lists his intellectual debts straightforwardly, beginning "The reader will recognize a method of criticism first formulated in respect of scientific concepts by Ernst Mach"; he then draws attention to only five books: Mach's Mechanics and Analysis of Sensations, two books by Henri Poincaré, and Percy W. Bridgman's recently published Logic of Modern Physics (1927). Skinner's dissertation was the start of a career that continued without deviation along the same direction for over five decades; the compass had been fixed by his first contacts with Loeb's and Mach's books. ${ }^{41}$

\section{PHILIPP FRANK (1884-1966)}

Skinner was probably the last scientist who could say he followed "a strictly Machian line," who could imagine having drunk directly from the pure source. As we penetrate further into the intellectual milieu in which American scholars existed about fifty years after James's solitary journey to meet Mach, we see an ever-increasing variety of intellectual debts, and a multiplicity of interactions of like-minded scientists and philosophers. In order to indicate the rest of Mach's long-term, variously mutated effect on U.S. thinkers by concrete examples, we shall shortly focus on one contemporary scholar who is usually referred to as the dean of philosophy in America (and who, as it happened, was one of Skinner's fellow students at Harvard during the 1930s), W. V. Quine. But to set the stage for understanding his early development, we must first consider some professional and personal relationships that existed during the first decades of this century in central Europe.

At the center of that network we find the physicist and philosopher Philipp Frank, a man who by training, imagination, and personality seemed selected by fate to play a key role in the wider transmission, reformulation, and transmutation of Mach's ideas. Born in Vienna in 1884 and educated as one of Ludwig Boltzmann's last students, he came to know Mach closely; was one of the originators of the group that became the Vienna Circle and the movement of twentieth-century scientific empiricism; was called to the university in Praguewhere Mach had been active for twenty-eight years and had left behind a loyal band of admirers-in 1912 as Einstein's successor; taught there in Mach's spirit for twenty-seven years; wrote some of the most sympathetic accounts of Mach's work and influence; remained one of the most active members of the Vienna Circle movement, organizer of some of its international meetings, indefatigable author, editor, and academic politician; and finally, with the great dispersal of European intellectuals in the 1930s, went to America, where he headed its successor movement in its various manifestations, including as president of the In-

\footnotetext{
41 "My debt was to the empiricism of Ernst Mach. If logical positivism can be said to have begun with the first issue of Erkenntnis [1929], I was far enough along in my own career to become a charter subscriber, as I was to its American equivalent, Philosophy of Science": ibid., p. 208.
} 
stitute for the Unity of Science. On his standing as a physicist, we have Einstein's testimony that he valued Frank so highly that he recommended no other successor when he left the University of Prague in $1912 .{ }^{42}$ Of Frank's work in the philosophy of science, it has been said, correctly, that it "combines informal logical analyses of the sciences with a vivid awareness of the psychological and social-cultural factors operating in the selection of problems, and in the acceptance or rejection of hypotheses, and which contribute to the shaping of styles of scientific theorizing. In a sense, this is a genuine sequel to the work of Ernst Mach."43

Much has been written about the Vienna Circle, its early debts to Mach, and the various later cross-currents and phases of the movement; lately there have also been signs of a considerable increase in interest in it by a new generation of scholars. At least a summary of its origins and fate will be needed here, with special attention to the role of Philipp Frank, a personal intermediary between Mach and his younger contemporaries, between the epistemologies of Mach and of those who succeeded him, and between the Europeans and the interested Americans.

Then a young Privatdozent in Vienna, Frank began in 1907 to meet regularly on Thursday nights in one of the old Viennese coffeehouses with a small group; it consisted of some students as well as Hans Hahn (later professor of mathematics at the University of Vienna) and the political economist and sociologist Otto Neurath (later organizer of adult education in social science for the city of Vienna). Others, such as the scientist Richard von Mises, joined them occasionally. Their long, informal discussions on current problems of philosophy and science, and particularly on the relation of reason and experience, resembled those in other early twentieth-century study circles of young intellectuals. The aim of these evening sessions, according to Frank, was to "bring about the closest possible rapprochement between philosophy and science," and also to avoid "the traditional ambiguity and obscurity of philosophy." 44

One of the first books on which this group seems to have centered attention was Abel Rey's La théorie de la physique chez les physiciens contemporains (1907), which, with extensive commentary on William Rankine, Mach, Ostwald, and Poincaré, announced a crisis of contemporary physics due to the failure of the mechanistic view that had been central to nineteenth-century physics. According to Rey, there was now no ontological basis left for science-it was only a collection of empirical recipes. With this, faith in science as such was undermined. Frank recalled that many readers thought it necessary to "return to the

\footnotetext{
${ }^{42}$ For writings on Mach see, e.g., his essays of 1917 and 1938, reprinted in Philipp Frank, Modern Science and Its Philosophy (Cambridge, Mass.: Harvard Univ. Press, 1949), Chs. 2 and 3. For brief essays on Frank by eleven colleagues, and a selected bibliography of his writings on the philosophy of science, see Robert S. Cohen and Marx W. Wartofsky, eds., Proceedings of the Boston Colloquium for the Philosophy of Science, 1962-1964 (Boston Studies in the Philosophy of Science, 2) (New York: Humanities Press, 1965), pp. ix-xxxiv; see also the entry for Frank in the Dictionary of Scientific Biography. Einstein's evaluation appears in his handwritten draft (probably of 1937) of a recommendation for Frank, in Albert Einstein Archive, Jewish National and University Library, Department of Manuscripts and Archives, Jerusalem, doc. 11-087.

${ }^{43}$ H. Feigl, "Some Major Issues and Developments in the Philosophy of Science of Logical Empiricism," in Feigl and Michael Scriven, eds., Minnesota Studies in the Philosophy of Science, Vol. 1 (Minneapolis: Univ. Minnesota Press, 1976), p. 4.

${ }^{44}$ Frank, Modern Science (cit. n. 42), p. 1.
} 
medieval ideas that may be characterized as the organismic conception of the world," with its religious implications. To Frank and his friends this prospect was intolerable. "In this critical situation our minds turned toward a solution that had been advanced about 25 years before by our local physicist and philosopher, Ernst Mach, namely that explanation is to be sought not by means of mechanistic or organismic conceptions, but only by giving a descriptive account of the phenomenon. In this way, Mach . . . saved the scientific worldpicture from going down along with the mechanistic picture."45

This group, like others, was not without its own criticism of Mach's views. With the advance of science it had become clear that Mach gave an insufficient role to mathematics and logic, and underestimated the fruitfulness of the atomistic hypothesis. The group therefore decided to build on, and as necessary to recast, Mach's ideas, to bring them into conformity with the modern situation as well as with the writings of related authors such as Poincaré and Duhem.

What the group fully approved was the antimetaphysical tendencies launched by Mach, which they felt to be not only a requirement for better logic but also of "great relevance for the social and cultural life." 46 They saw Mach's function as analogous to that of the eighteenth-century Enlightenment figures, and spoke of reading Mach "drunk with soberness"-the phrase often applied to Voltaire. On the other hand, while they joined in Machian empiricism as a starting point, the group as a whole showed less interest in Mach's forays into the history of science, although Frank was and remained an exception in this respect, as Carnap later attested. ${ }^{47}$

Perhaps the first product of this discussion circle was Frank's public debut on the scene, his 1907 article "Kausalgesetz und Erfahrung" (which he later expanded into the widely read book Das Kausalgesetz und seine Grenzen). It was clearly written under the influence of Mach and Poincaré, both of whom would have agreed with much in it. It quickly aroused comments from two very different quarters: V. I. Lenin, who savaged it, and Albert Einstein, who became a lifelong friend. ${ }^{48}$

${ }^{45}$ Ibid., pp. 3, 6 .

${ }^{46}$ Ibid., p. 34. By "metaphysical" the circle members meant in-principle unverifiable and unfalsifiable.

47 "[Philipp Frank] was familiar with the history of science and much interested in the sociology of scientific activity, for which he collected comprehensive materials from history. Both because of his historical interest and his sound common sense, he was often wary of any proposed thesis that seemed to him overly radical, or of any point of view that seemed too formalistic. Thus, in a way similar to Neurath, he often brought the abstract discussion among the logicians back to the consideration of concrete situations": Rudolf Carnap, "Intellectual Autobiography," in The Philosophy of Rudolf Carnap, ed. Paul A. Schilpp (La Salle, Ill.: Open Court, 1963), p. 32.

${ }^{48}$ Philipp Frank, "Kausalgesetz und Erfahrung," Annalen der Naturphilosophie, 1907, 6:445-450; see also "Mechanismus oder Vitalismus?" ibid., 1908, 7:393-409. Mach may well have read these, and also read or heard of Frank's public lecture of 4 Dec. 1909 at the Physikalische Gesellschaft at the University of Vienna on the topic "Does Absolute Motion Exist?" This piece was later published: Philipp Frank, "Gibt es eine absolute Bewegung?" in Wissenschaftliche Beilage zum dreiundzwanzigsten Jahresbericht (1910) der Philosophischen Gesellschaft an der Universität zu Wien (Leipzig: Johann Ambrosius Barth, 1911), pp. 1-19. In it, too, Frank explained, extended, and defended Mach's ideas.

Lenin commented on Frank in Ch. 3 of Materialism and Empirio-Criticism (1909), as part of an attack concentrated mainly on Mach and Alexander Bogdanov. He dismissed Frank as a Kantian idealist. This attack might have been most uncomfortable, but happily Frank did not find out about it until the 1920s. Later, as he told me, Lenin's comment became useful to him in a completely unex- 
It would be interesting to know precisely when Mach came to know Frank, for that contact-which "helped seal Frank's lifelong loyalty to most aspects of Mach's philosophy of science"-started a relationship of the greatest importance for the propagation of Machian ideas in Europe and the United States during the next six decades. ${ }^{49}$ The case illustrates again-as for James, Loeb, Einstein, and many others-the power of Mach's ideas and personality in captivating rising young scientists.

The earliest known personal interaction between Mach and Frank came in 1910, the result of Mach's growing impatience in trying to understand Einstein's and Hermann Minkowski's work on relativity; he felt the need to understand better the mathematically complex developments of the growing theory, about which he had become concerned, not least because of what he frankly called (in a letter of 20 Nov. 1912 to Hugo Dingler) the "weakness of my mathematical education." After a rather urgent search, Mach found an authoritative helper in Frank, who had been recommended to him (in a letter of 5 June 1910 from the physicist Gustav Jäger) as "a man who, I think, is the best qualified of the Vienna physicists." Their meeting was followed by Frank's preparation of an essay on the theory of relativity that, as he wrote Mach, "is understandable to nonmathematicians, as you requested in your letter, Herr Hofrat." ${ }^{50}$ In Frank's published papers on relativity around that time, we see the work of a fine physicist and a masterful presenter of the special relativity theory, but also of a conciliator; for Frank stressed the continuities with pre-Minkowskian sensibilities, for example, by avoiding the use of the tell-tale square root of negative quantities involving $t$, which had startled so many who had encountered Minkowski's work directly. (Doing that was a point of pride for Frank, as he once remarked to me.) What most interests us here is that the letter fixes the initial time and tenor of the bonding between Mach and the man who, as will be shown, was to play such a large role in the transformation and transmigration of Machian teachings.

\section{A HARVEST OF MACH'S SEEDS}

At the end of World War I, with the establishment of new democratic republics in central Europe and the general desire, at least among the younger generation, to

pected way. While Frank was teaching at Harvard University, he was also doing consulting work for the U.S. Navy. Either in this connection, or as a result of the general anticommunist hysteria in the United States during the McCarthyite days after the war, Frank one day received a visit at his home from two FBI men. They had come to investigate his background and orientation, which seemed to them to have been suspiciously on the liberal side. Frank, no doubt with his usual quizzical smile, inquired whether they thought he might be a spy for the Russians, and to answer his own question, he went to his bookcase, fished out the copy of Lenin's book, and opened it to the passage where Lenin attacked him personally. As Frank ended this story, the two FBI men practically saluted him, and left speedily and satisfied.

In his first contact, Einstein made the objection that the simplicity of terminology in the law of causality, and therefore the "simplicity of nature," are not reducible to conventions. Frank learned from the exchange that "logic needs a drop of pragmatic oil": Frank, Modern Science, p. 11.

49 Blackmore, Ernst Mach (cit. n. 6), p. 183.

50 Mach to Hugo Dingler, 20 Nov. 1912, in Blackmore and Hentschel, eds., Ernst Mach als Aussenseiter (cit. n. 1), pp. 106-107; and Gustav Jäger to Mach, 5 June 1910, in Blackmore, Ernst Mach (cit. n. 6), p. 263. Mach's search for help is described in Gerald Holton, "More on Mach and Einstein," Methodology and Science, 1989, 22:67-81. 
bring their civilization into a new, modern phase, Mach's ideas continued to have a special attraction among intellectuals in Vienna even before the formation of the Vienna Circle around Moritz Schlick. ${ }^{51}$

Brought to Vienna in 1922, Schlick, originally a student of Max Planck but with a very different philosophical orientation, was indeed a worthy successor to the philosophy of science chair at the university that had been held by Mach and for two years by Boltzmann. With Schlick as a new intellectual center in Vienna, the formerly open, Thursday-night conversations at the Café Central became wellstructured, closed Thursday-night seminars in which Frank was a commuting member from Prague. ${ }^{52}$ The meetings, involving highly competent individuals from a great variety of professions, occasionally allowed invited guests, such as the Americans to be noted shortly; this opportunity for making acquaintances would have long-range consequences. Another significant event was the arrival in 1926 of the former student of Gottlob Frege, Rudoll Carnap, brought to Vienna as Privatdozent in 1926 by Schlick. Carnap, who had been much influenced by Bertrand Russell and Alfred North Whitehead, published his seminal book, Der logische Aufbau der Welt, in 1928, and this, in Frank's words, was seen by "our Viennese group" as the long-hoped-for "integration of Mach and Poincaré." 53

Because of Carnap's key position, together with Frank, in the later, American phase of the movement, it will be useful to glance here at his book. Its debt to Mach, together with Avenarius, Poincaré, Russell, and Whitehead, is indicated in its first pages. The "elementary concepts" of Carnap's system are immediate sense impressions and the relations of similarity and diversity between them. Frank tells us that the book also, to his and Carnap's own astonishment, reminded them strongly of William James's pragmatism-for example, "that the meaning of any statement is given by ... . what it means as a direction for human behavior"-and thus showed a promising affinity of their movement with "kindred spirits beyond the Atlantic in the United States." 54

In his preface Carnap explained that a main impulse was to "banish metaphysics from philosophy, because its theses cannot be rationally justified"; and on the second page of the text, as if touching on another of Mach's main tasks and echoing the key notion of the Aufruf of 1911-1912, he declared his intention to be

${ }^{51}$ A good witness to this was Friedrich von Hayek, who studied in Vienna in 1918-1921. He reported that his circle "sought arguments against metaphysics, which we found in Mach"; see W. F. Merzkirch, ed., Symposium (cit. n. 5), p. 42.

52 There are various accounts of the names of the members of the Vienna Circle at its height. Putting together the overlapping lists given by Otto Neurath, Empiricism and Sociology (ed. Marie Neurath and Robert S. Cohen [Dordrecht: Reidel, 1973]), pp. $318 \mathrm{ff}$, , and Victor Kraft, Der Wiener Kreis: Der Ursprung des Neopositivismus (Vienna: Springer Verlag, 1950), pp. 3-4, one arrives at eighteen core members and nine strong sympathizers; but if one also adds active collaborators who published in major Vienna Circle programs, one would have to include such figures as Richard von Mises, then in Berlin. One estimate is that over a third of the total group eventually came to the United States.

Additional names of foreign visitors are given in Herbert Feigl, "Logical Empiricism," in Twentieth Century Philosophy, ed. Dagobert D. Runes (New York: Philosophical Library, 1943), p. 406.

${ }^{53}$ Frank, Modern Science (cit. n. 42), p. 33. Similarly, Feigl wrote, Carnap's Aufbau "seemed indeed the fulfillment of the original intentions of Mach's positivism, as well as a brilliant application of the tools of modern logic to some of the perennial issues of epistemology": "Wiener Kreis in America" (cit. n. 22), p. 635. The English translation, The Logical Structure of the World, was published in 1969 by the Univ. California Press.

${ }^{54}$ Frank, Modern Science, p. 33. 
the construction of a system of concepts not only of natural science but of one total knowledge, a Gesamtwissenschaft: "Only if it becomes possible to build up a unified system of all concepts will it be possible to overcome the splintering of the Gesamtwissenschaft into separate part-sciences that stand, one next to the other, without relationship." In this way it would be possible to attain an "intersubjective, objective world . . . identical for all observers," and so make, as it were, an end run around supposedly essential differences between physics, biology, psychology, and so forth. ${ }^{55}$ The desired unification was to encompass all fields of science and scholarship generally, and unity among them came to be looked for in terms of a commonality of concepts, of laws, of methods (including the unmasking of "meaningless" problems), and of the social community of researchers.

The movement was entering its most intense period. November 1928 saw the founding of the "Verein Ernst Mach" as the "official" forum of the Vienna Circle, with the stated goal to "further and propagate a scientific worldview" and to achieve an Einheitswissenschaft. (A counterpart organization to the circle around Schlick had been formed, as noted, in Berlin, renamed in 1931 "Gesellschaft für wissenschaftliche Philosophie.") The very name of the Verein demonstrated its intellectual debts, despite the differences mentioned earlier. The circle's devotion to logic and to the clarification of the meaning of propositions accentuated a range of additional influences on it, from Brentano to Russell and Ludwig Wittgenstein. How direct and strong the ties now were with Mach, and with which aspects of Mach, became ever more discussable. Frank was perhaps the most faithful and persistent follower, calling "the harvest of the seeds scattered by Mach ... particularly rich and in the strictest accordance with his true intentions." As a shrewd observer from the other side of the Atlantic put it on noting the place now given to logic: "Mach, it is true, has recently been canonized and made the father of a new school of philosophy in Vienna. . . But this Mach redivivus is the positivistic and not the pragmatistic Mach." 56

But sorting out unambiguously the differences with Mach's original teachings is extremely difficult, for two intimately connected reasons. As Mach always insisted, he had no coherent, easily categorized, and time-stable "philosophy"; and that made it easy for different scholars to attach themselves to different fragments or versions of an evolving point of view. Also, the Vienna Circle and its sympathizers elsewhere did not form a well-synchronized group of mere disciples, but included a great variety of energetic and imaginative individuals with different backgrounds. Thus Carnap and Schlick could argue in their letters as late as 1926 about what Machism really meant, as did Neurath in his letters to von Mises even in 1939, with Mach's ghost hovering over the discussants.

The most spectacular and widely noted act of the group was the publication of the manifesto Wissenschaftliche Weltauffassung: Der Wiener Kreis (1929), under the authorship of Carnap, Hans Hahn, and Otto Neurath. This document spelled out the group's doctrines in persuasive and generally accessible terms, taking great care to avoid wrong associations and warning against the confusion between the emotional and informational functions of language. The slim booklet

\footnotetext{
${ }^{55}$ Rudolf Carnap, Der logische Aufbau der Welt, 1st ed. (Hamburg: Felix Meiner Verlag, 1928), p. xix, preface of May 1928, pp. 2-3.

${ }^{56}$ Frank, Modern Science, p. 89 (the essay was written in 1938); and Perry, Thought and Character of William James (cit. n. 24), Vol. 2, p. 580.
} 
announced a fundamental aim of the Vienna Circle philosophy to be an antimetaphysical, unified science ("Einheitswissenschaft"), in which every symbol denotes "something 'real' if it is coherent with the total structure of facts of experience." 57 It thus addressed what Carl G. Hempel, who studied in Vienna in 1929-1930, identified as the group's common aim of removing the "strong intellectual discomfort" (starkes intellectuelles Unbehagen) that philosophy, unlike science, "had had so little success with its efforts to solve certain central problems, above all in metaphysics." 58 But its larger ambition was to be a tocsin for modernism, going far beyond the natural sciences and logic. It asked for a world conception inspired by Enlightenment ideas that encompassed the modernization of all life, from economics to architecture, from the education of workers to the formation of the tools of thought of modern empiricism that are needed for the conduct of "private and public life," as well as "business and social life." The memorable concluding sentence of this manifesto was, "The scientific world conception serves life, and in turn is taken up by life." 59

Not all members of the circle were of one mind politically; the spectrum ran from the agitated Neurath to the almost apolitical Schlick. But for the most part they shared a revulsion against the oppressive residue of medievalism in so much of Austrian intellectual and political life, longed instead for a neue Sachlichkeit (a new sober factuality), and agreed in their liberal, secular extraphilosophical aims just as they were all fairly unified on the central philosophical ones. Carnap's autobiographical statement on this point is important, both because it records the predominant spirit and because it overlapped with the point of view of a number of Americans who later sponsored the immigration of key members of the circle.

I have not been active in party politics, but I was always interested in political principles and I have never shied away from professing my point of view. All of us in the Vienna Circle took a strong interest in the political events in our country, in Europe, and in the world. These problems were discussed privately, not in the Circle which was devoted to theoretical questions. I think that nearly all of us shared the following three views as a matter of course which hardly needed any discussion. The first is the view that man has no supernatural protectors or enemies and that therefore whatever can be done to improve life is the task of man himself. Second, we had the conviction that mankind is able to change the conditions of life in such a way that many of the sufferings of today may be avoided and that the external and the internal situation of life for the individual, the community, and finally for humanity will be essentially improved. The third is the view that all deliberate action presupposes

\footnotetext{
${ }^{57}$ Rudolf Carnap, Hans Hahn, and Otto Neurath, Wissenschaftliche Weltauffassung: Der Wiener Kreis (Vienna: Artur Wolf Verlag, 1929), pp. 15, 18 (my translation); for an English translation see Otto Neurath, Empiricism and Sociology (cit. n. 52). Frank explained that the word "Weltauffassung" was chosen to avoid the metaphysically charged and Germanic word "Weltanschauung," and that the subtitle "Der Wiener Kreis" was added at Neurath's suggestion to make the title "less dry" by evoking Vienna waltzes, Vienna Woods, "and other things on the pleasant side of life": Modern Science, p. 38.

${ }^{58}$ Carl G. Hempel, "Der Wiener Kreis: Eine persönliche Perspektive," in Wittgenstein, der Wiener Kreis und der kritische Rationalismus, ed. Hal Berghel, Adolf Hübner, and Eckehart Köhler (Vienna: Hölder-Pichler-Tempsky, 1979), pp. 21-26, on p. 21. Among brief recent evaluations of the history of logical positivism, perhaps the most useful ones for students are in R. C. Olby, G. N. Cantor, J. R. R. Christie, and M. J. Hodge, eds., Companion to the History of Modern Science (London/New York: Routledge, 1990), Ch. 54; Smith, Behaviorism and Logical Positivism (cit. n. 21), Ch. 2; and Robert N. Proctor, Value-Free Science? (Cambridge, Mass.: Harvard Univ. Press, 1991), Ch. 12.

${ }^{59}$ Carnap et al., Wiener Kreis (cit. n. 57), p. 30. Similarly, the fundamental aim of Richard von Mises's Kleines Lehrbuch des Positivismus (1939; Frankfurt am Main: Suhrkamp Verlag, 1990) was the renovation of culture in all its aspects.
} 
knowledge of the world, that the scientific method is the best method of acquiring knowledge and that therefore science must be regarded as one of the most valuable instruments for the improvement of life. In Vienna we had no names for these views; if we look for a brief designation in American terminology for the combination of these three convictions, the best would seem to be "scientific humanism." 60

The wide variety of programs launched by the group is therefore not surprising; it included, for example, public lectures in Vienna such as Carnap's "On God and Soul: Pseudo-Problems of Metaphysics and Theology," and one by Philipp Frank's brother, the distinguished architect Josef Frank, entitled "Modern World Conception and Modern Architecture." As Peter Galison has persuasively argued, the ambition of Carnap's Aufbau was to be a manifesto of modernism, and the whole work of the Vienna Circle lent itself to an attempt at a new integration of science, philosophy, art, architecture, and social values. ${ }^{61}$ Thus the welcome that adherents of the Bauhaus later would experience in the United States was not unconnected to that extended to the Vienna Circle members. Similarly, Herbert Feigl was dispatched in 1929 "as the first 'emissary' of the Vienna Circle to Bauhaus Dessau" because it was considered to have a related, progressive ideology. And feeling that there "was a Zeitgeist thoroughly congenial to our Viennese position" waiting across the ocean, the main principles were exported to the United States in a paper by Feigl and Alfred E. Blumberg-a publication that also provided the movement "its international trade name."62

The Vienna Circle and the related Berlin assembly had felt frustrated to be a "small number of dissident people hemmed in by the vast ocean of German school philosophy which was more or less a development of Kantian metaphysics."63 By 1929 the internal morale, energy, and ambition of the group were so

${ }^{60}$ Rudolf Carnap, “Intellectual Autobiography” (cit. n. 47), pp. 82-83. For a debate about the role of politics in the Vienna Circle see the contributions by Barry Smith and Gerhard Zecha in The Vienna Circle and Lvov-Warsaw School, ed. Klemens Szaniawski (Dordrecht: Kluwer, 1989).

${ }^{61}$ These lectures were announced in Erkenntnis, 1930-1931, 1:174. Peter Galison, "History, Philosophy, and the Central Metaphor," Science in Context, 1988, 2:182-198; and Galison, "Aufbau/ Bauhaus: Logical Positivism and Architectural Modernism," Critical Inquiry, 1990, 16:709-752.

${ }^{62}$ Feigl, "Wiener Kreis in America" (cit. n. 22), pp. 637, 645; Feigl and A. E. Blumberg, "Logical Positivism: A New Movement in European Philosophy," Journal of Philosophy, 1931, 28:281-297 (Blumberg was one of the young Americans Feigl persuaded to come to study in Vienna); and Frank, Modern Science (cit. n. 42), p. 38. The group's self-identifying term "logical positivism" gave way, from about 1936, to "logical empiricism" or "scientific empiricism," for reasons sketched, e.g., in Feigl, "Wiener Kreis in America"; and Joergen Joergensen, "The Development of Logical Empiricism," in Foundations of the Unity of Science: Toward an International Encyclopedia of Unified Science, ed. Otto Neurath, Rudolf Carnap, and Charles Morris, 2 vols., Vol. 2 (Chicago: Univ. Chicago Press, 1970), pp. 845-936.

${ }^{63}$ Frank, Modern Science, p. 47. For a debate why logical empiricism developed more easily in Austria than in Germany see Otto Neurath, "Le développement du cercle de Vienne et l'avenir de l'empirisme logique," Actualités Scientifiques et Industrielles, no. 290 (Paris: Hermann \& Cie, 1936); Neurath, Gesammelte philosophische und methodologische Schriften, ed. Rudolf Haller and $\mathrm{H}$. Rutte, 2 vols. (Vienna: Hölder-Pichler-Tempsky, 1981); Smith's and Zecka's articles in Vienna Circle, ed. Szaniawski (cit. n. 60); Haller, "Wittgenstein: An Austrian Enigma," in Austrian Philosophy Studies and Texts, ed. J. C. Nyíri (Munich: Philosophia Verlag, 1981), pp. 91-112; Friedrich Stadler, Vom Positivismus zur wissenschaftlichen Weltauffassung (Vienna: Löcker Verlag, 1982); Carl G. Hempel and F. Stadler in Wittgenstein, ed. Berghel et al. (cit. n. 58); and several essays in J. C. Nyíri, ed., Von Bolzano zu Wittgenstein (Vienna: Hölder-Pichler-Tempsky, 1986). The contrast between philosophy as taught in the 1930s in Germany and the United States emerges graphically by comparing Sidney Hook, "A Personal Impression of Contemporary German Philosophy," Journal of Philosophy, 1930, 27:141-160, and Charles W. Morris, "Aspects of Recent American Scientific Philosophy," Erkenntnis, 1935, 5:142-150. 
high that an intense search for larger public forums ensued-the operational indication that a movement had emerged. One step was the founding of the journal Erkenntnis, the main mouthpiece of the movement, edited by Carnap and Hans Reichenbach (later, in its American phase, continued as the Journal for the Unity of Science, published by the University of Chicago Press). Also, two series of books were launched, with Frank as coeditor: Schriften zur wissenschaftlichen Weltauffassung (10 vols.) and Einheitswissenschaft (7 vols.); to these were added, starting in 1938, the Library of Unified Science Series and the International Encyclopedia of Unified Science.

Yet another move, also with important consequences, was initiated by Frank. As the professor of theoretical physics at what was now called the "German University" at Prague, he was chairman of the local committee of the 1929 annual meeting of physicists and mathematicians from German-speaking Europe, scheduled for Prague, as well as chairman of the physicists' portion of the congress. Therefore he could not be refused his request to include a session, jointly sponsored by the Ernst-Mach-Verein of Vienna and the Society for Empirical Philosophy of Berlin, and advertised as the First Congress for the Theory of Knowledge of the Exact Sciences. It seemed an ideal moment to try to convert the German physicists. In his own lecture at the opening session Frank traced the rise of scientific empiricism from Mach, indicated its overlap with James's pragmatism, and ended with the challenge, "There are no boundaries between science and philosophy if only one formulates the task of physics in accordance with the doctrines of Ernst Mach."64

If Frank had hoped to introduce the new philosophy to the scientists and thereby shake their "sentimental ties to Kantianism" immediately, he did not succeed. ${ }^{65}$ The majority of the audience was hostile. Yet for the movement the Prague meeting became the model for a whole series of congresses under different titles (e.g., International Congress for the Unity of Science) in different countries: in 1930 in Königsberg; 1934 in Paris (with papers read by two Americans, Ernest Nagel and Charles Morris); 1935 again in Paris; 1936 in Copenhagen, with Niels Bohr's involvement (see Figure 3); 1937 again in Paris; 1938 in Cambridge, England (with papers by Max Black, V. Lenzen, and D. C. Williams from the United States); September 1939 in Cambridge, Massachusetts, and 1941 in Chicago.

There were two other important results of that first meeting. One was the establishment of the self-confident internationalism of the movement, which would have important benefits when foreign acquaintances were later called upon to help in transplanting scholars in search of a refuge. More immediately, in the aftermath of the congress, Frank succeeded in creating at the University of Prague a special professorship of the philosophy of science, and in having Rudolf Carnap appointed to it. Carnap's arrival in 1931 fortified this outpost of empiricist philosophy on Mach's own home ground. "From 1931 on, we had in this way a new center of the 'scientific world conception' at the University of Prague." it turned out, they also had another magnet to attract American visitors.

\footnotetext{
${ }^{64}$ Philipp Frank, "Was bedeuten die gegenwärtigen physikalischen Theorien für die allgemeine Erkenntnislehre?" Erkenntnis, 1930-1931, 1:126-157, on p. 157.

${ }^{65}$ Frank, Modern Science (cit. n. 42), p. 40.

66 Ibid., p. 45.
} 


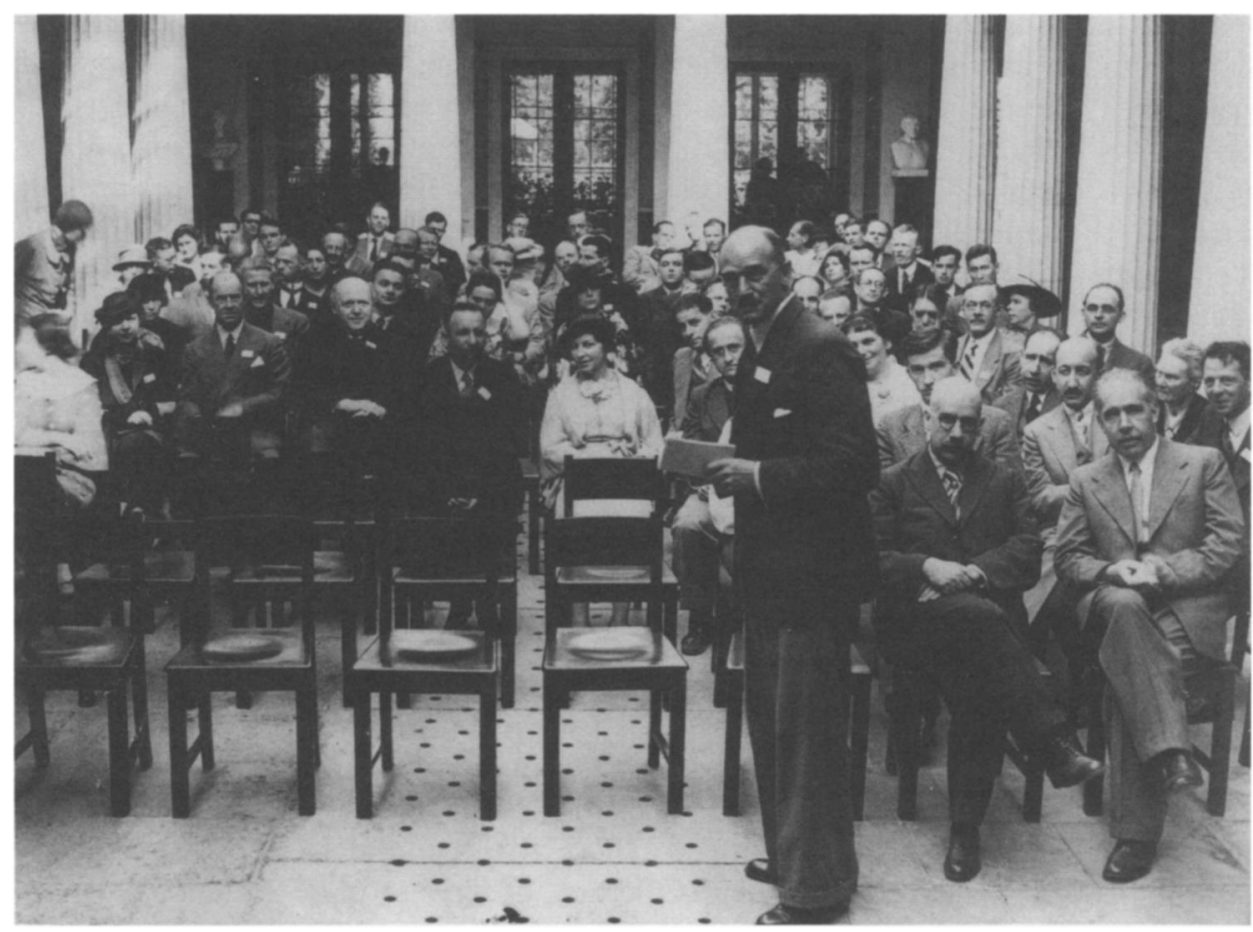

Flgure 3. Session at Second International Congress for Unity of Science, Copenhagen, 21-26 June 1936, on the topic "The Causality Problem." (Courtesy of Harvard University Archives, P. Frank file.) In the front row from left: Niels Bohr and Philipp Frank. Between them Harald Bohr (r.) and Georg von Hevesy; and, to Bohr's left, the educator Hannah Adler and the psychologist Edgar Rubin. Among others visible are Otto Neurath (third from left in fourth row), Carl Hempel (behind him, toward the right), and Karl Popper (third from Hempel to the right). For the participation of Werner Heisenberg, Pascual Jordan, and other German scientists see Dieter Hoffmann, "Zur Teilname deutscher Physiker an den Kopenhagener Physikerkonferenzen," NTM: Zeitschrift für Geschichte der Naturwissenschaft, Technik und Medizin, 1988, 25:49-55.

With Germany still largely in the sway of Kantian idealism, the groups in Vienna and Prague now thought it all the more important to seek allies in Great Britain, to a certain extent in France, and above all in the United States, where, as noted, the ground had been prepared by the work of Peirce, James, and to some extent John Dewey and others; by the writings of more recent sympathizers there, such as Bridgman at Harvard and Morris at Chicago; and by the travels of Schlick and Feigl. There started a flow of visitors from America. Among those who came to Vienna and Prague to learn and discuss were Nagel, Morris, Dickinson S. Miller, and a young man named W. V. Quine.

One may well ask what was so special about the European group that it reached out to young intellectuals on the other side of the Atlantic. At least two forces were at work. One was the lack of major figures in America itself; Feigl, who had emigrated there in 1931 , observed that while there were a few important philosophizing scientists (and even they were on the whole isolated, and spread across the continent), "perhaps the only prominent American philosopher of science after C. S. Peirce" was Morris Raphael Cohen of City College in New York; 
and Cohen and A. C. Benjamin were "the only really distinct representatives and teachers of the philosophy of science" in the whole country. ${ }^{67}$

This lack would be filled within a decade, in large measure by immigrants from the Continental group and their students. The second factor that increased the attraction of Vienna, Prague, and associated centers for these young philosophers was the remarkable wealth of philosophers of science of various related schools in German-speaking Europe, particularly those of Austrian origin. (Just among the latter, Nyíri lists, in roughly chronological order, the following: Bolzano, Mach, Karl Menger, Boltzmann, Höfler, Husserl, Wittgenstein, Hahn, Neurath, Feigl, Frank, Popper, Fleck, von Mises, Polanyi, and others.) It is still rather puzzling what produced this efflorescence despite the fact that the university in Vienna tended to marginalize them; but their presence and perhaps their very marginalization created a hospitable ambience for foreign visitors. ${ }^{68}$

During the early 1930s, the movement's most confident period, the Prague branch continued to be led by Frank, who was now director of the Institute of Theoretical Physics. Frank and Carnap shared an office that once had been Einstein's. As another student of Frank, Peter Bergmann, later recalled, the institute was located on the top floor of the academic building at Vinična 3, "conveniently across the street from the psychiatric hospital. . . The patients would look at us, and we at the patients, often wondering who was 'in' and who was 'out.' "69 But here a reminder is in order that the clouds of madness were now gathering over Europe, heralding a tragic ending for many intellectuals of the movement, and of the whole inheritance of Mach's influence on thought on the Continent. In 1936 Moritz Schlick was murdered by a deranged student on the steps of the University of Vienna. Two years earlier the protofascist government of the Austrian Chancellor Engelbert Dollfuss had dissolved the Ernst-Mach-Verein in a police action, charging that it had been politically engaged on the side of the Social Democrats.

\section{W. V. QUINE}

Having set forth the necessary topography and time line, we can pick up the thread of the early development of W. V. Quine, now widely regarded as the central figure in the philosophy of the postpositivistic era, the synthesizer of the problems of language versus theory and science versus philosophy. ${ }^{70}$ In Quine's

\footnotetext{
${ }^{67}$ Feigl, "Wiener Kreis in America" (cit. n. 22), p. 660. See also Daniel J. Wilson, "Science and the Crisis of Confidence in American Philosophy," Trans. C.S. Peirce Soc., 1987, 23:235-262.

${ }^{68}$ J. C. Nyíri, "The Austrian Element in the Philosophy of Science," in Bolzano zu Wittgenstein, ed. Nyíri (cit. n. 63), pp. 141-146, on p. 142. The marginalization of these philosophers has been well documented in Friedrich Stadler, "Aspekte des gesellschaftlichen Hintergrunds und Standorts des Wiener Kreises am Beispiel der Universität Wien," in Wittgenstein, ed. Berghel et al. (cit. n. 58), pp. 41-59.

${ }^{69}$ Peter Bergmann, "Homage to Professor Philipp G. Frank," in Proceedings of the Boston Colloquium, ed. Cohen and Wartofsky (cit. n. 42), pp. ix-x.

${ }^{70}$ See Dirk Koppelberg, Die Aufhebung der analytischen Philosophie: Quine als Synthese von Carnap und Neurath (Frankfurt am Main: Suhrkamp Verlag, 1987). I shall base some of my points on Koppelberg's book and on Quine's own writings, including his autobiographical accounts, in The Philosophy of W. V. Quine, ed. L. E. Hahn and Paul A. Schilpp (Library of Living Philosophers, 18) (La Salle, Ill.: Open Court, 1986); W. V. Quine, The Time of My Life: An Autobiography (Cambridge, Mass.: MIT Press, 1985); and Richard Creath, ed., Dear Carnap, Dear Van: The Quine-Carnap Correspondence and Related Work (Berkeley: Univ. California Press, 1990). I also thank Professor Quine for comments on an early draft. See also his "Comment on Koppelberg," in Perspectives on Quine, ed. William Barrett and Roger F. Gibson (Oxford: Basil Blackwell, 1990), p. 212.
} 
philosophy, as he has pointed out, the central question is, "Given only the evidence of our senses, how do we arrive at a theory of the world?" Starting with his essays "Truth by Convention" (1935) and "Two Dogmas of Empiricism" (1951), he sought the answer in what has been called a holistic or naturalistic version of empiricism that can trace a line of descent from Auguste Comte, Mach, and the Vienna Circle. To put it very briefly, the so-called Duhem-Quine thesis declares that only the body of a theory as a whole can be properly subjected to empirical test, rather than each isolated hypothesis. As Quine wrote,

A conflict with experience at the periphery occasions readjustments in the interior of the field. . . . Having reevaluated one statement we must reevaluate some others, which may be statements logically connected with the first or may be statements of logical connections themselves. But the total field is so under-determined by its boundary conditions, experience, that there is much latitude of choice as to what statements to reevaluate in the light of any single contrary experience. ${ }^{71}$

In essence, Quine's position can be seen as a critique and a restructuring of the logical empiricism of the Vienna Circle, so to speak from the inside, and particularly, as Quine has acknowledged, as a result of his contact with Rudolf Carnap: "I, like many, have been influenced more by him than by any other philosopher." In his searching analysis, Dirk Koppelberg sees Quine as the synthesizer of Carnap's and Neurath's ideas-a "continuation and finalization" of the empiricism of the Vienna Circle. ${ }^{72}$

From his autobiographies, we know Quine's personal preparation. In his high school years he had read James's Pragmatism "compulsively" (i.e., uncritically), and at Oberlin College, where he was studying mathematics, he was exposed to the work of John B. Watson in a psychology course and discovered Russell. By 1930 he was at Harvard for graduate work, and there he met Herbert Feigl, who had come on a Rockefeller Foundation fellowship to study for nine months under Bridgman. Feigl recalled encountering the philosophers C. I. Lewis, Henry Sheffer, Susanne K. Langer, and Alfred North Whitehead; but he was "especially impressed" with Quine. One result was that when Quine won a traveling study fellowship for 1932-1933, he took Feigl's advice "to start the year at Vienna"; he was also urged to go there by a fellow student, John Cooley, "who had discovered Carnap's Logische Aufbau der Welt."73

A road had been chosen. Quine arrived in Vienna in September 1932 for a five-month stay, and at once plunged into exciting waters-attending Schlick's lectures and, at Schlick's invitation, the weekly Vienna Circle evenings (the first talk he heard was Friedrich Waismann's report on Bridgman's Logic of Modern Physics). He met there members such as Kurt Gödel, Karl Menger, Hans Hahn, Olga Hahn-Neurath, Gustav Bergmann, and visitors such as Hans Reichenbach

${ }^{71}$ W. V. Quine, The Roots of Reference (La Salle, Ill.: Open Court, 1974), p. 1; and Quine, From a Logical Point of View (New York: Harper Torchbooks, 1963), p. 42 (in an essay written in 1953).

${ }_{72}$ W. V. Quine, “Carnap's Positivistic Travail," Fundamenta Scientiae, 1984, 5:325-334, on p. 333; and Koppelberg, Die Aufhebung (cit. n. 70), p. 20. On the other hand Quine, in "Comment on Koppelberg" (cit. n. 70), notes that he arrived at positions similar to Neurath's without traceable influence and, surprisingly, that he did not get from Duhem the holism associated with him, but was alerted to Duhem only after the publication of his crucial 1951 essay "Two Dogmas"- "by both Hempel and Philipp Frank."

${ }^{73}$ Hahn and Schilpp, eds., Philosophy of Quine (cit. n. 70), p. 6; Feigl, "Wiener Kreis in America" (cit. n. 22), p. 647; and Quine, Time of My Life (cit. n. 70), p. 86. 
and A. J. Ayer. Quine also saw Schlick and his American wife socially, and even lectured on his doctoral thesis at one of the Vienna Circle meetings.

But he had missed Carnap, who had moved to Prague. Therefore Quine went on to Prague for six weeks in the winter of 1933, at Carnap's invitation. There he heard Philipp Frank lecture and "eagerly attended" Carnap's lecture course at the Physics Institute. No doubt attracted by Quine's qualities, Carnap opened up to the young man, allowing him in his seminar and giving him his articles and books, including the recent Logische Aufbau. This contact was for Quine "my most notable experience of being intellectually fired by a living teacher rather than by a book." ${ }^{74}$ Quine takes credit for bringing news of Carnap's work back to Harvard by giving several lectures on it. When he was appointed instructor at Harvard-after spending three years (1933-1935) as a colleague of B. F. Skinner in Harvard's newly founded elite Society of Fellows-he taught what he called "a philosophy course along Carnap's lines." 75 A new torch had been lit.

When the increasing persecutions in the late 1930s brought more of the European intellectuals to the United States, Quine valued their reinforcing but ecumenical fellowship. He was secretary of the fifth International Congress for the Unity of Science, a summit meeting of scholars sympathetic to the movement, held at Harvard on 3-9 September 1939-just as the war broke out in Europe. Papers were presented by, or for, a group so distinguished and varied that it is appropriate to list the better known among them:
A. C. Benjamin
R. Carnap
A. Church
G. de Santillana
H. Feigl
P. Frank
Kurt Goldstein
H. Gomperz
K. Grelling
C. G. Hempel
L. J. Henderson
S. Hook
Werner Jaeger
Joergen Joergensen
H. M. Kannen
A. V. Karpov
Felix Kaufmann
Hans Kelsen
Susanne K. Langer
Kurt Lewin

Janina Lindenbaum-Hosiasson

R. B. Lindsay

Hans Margenau

$\mathrm{R}$. von Mises

Charles Morris

Ernest Nagel

Otto Neurath

F. S. C. Northrop

Paul Oppenheim

Talcott Parsons

W. V. Quine

Hans Reichenbach

Louis Rougier

George Sarton

S. S. Stevens

Alfred Tarski

F. Waismann

D. C. Williams

Robert S. Woodbury

Edgar Zilsel

\footnotetext{
${ }^{74}$ Quine, Time of My Life, p. 98. In his "Intellectual Autobiography" (cit. n. 47), p. 34, Carnap notes that Morris and Quine came to Prague: "Both were strongly attracted by our way of philosophizing and later helped to make it known in America."

${ }^{75}$ One result of Quine's introduction of Carnap's work was Carnap's visiting year at Harvard in 1936 and the honorary degree awarded him at Harvard's Tercentenary Celebration that year. Charles Morris, who had spent the summer of 1934 in Prague, arranged for Carnap's professorship at the University of Chicago from 1936, and also helped to find positions in the United States for Carl Hempel and Hans Reichenbach; see Feigl, "Wiener Kreis in America" (cit. n. 22), p. 648. For the quotation see Hahn and Schilpp, eds., Philosophy of Quine, p. 16. The "Lectures on Carnap" (given 8-22 Nov. 1934) have been published in Creath, ed., Dear Carnap, Dear Van (cit. n. 70). The letters between Carnap and Quine show the symbiotic relation at work, while Carnap's "Intellectual Autobiography" tends to accentuate their eventual differences.
} 
Some, including von Mises, had come to the United States as visitors to attend the congress; but now they would remain, increasing the presence and power of the movement as it developed in its American phase. Of this congress, Quine later wrote simply: "Basically this was the Vienna Circle, with accretions, in international exile." ${ }^{76}$ If a date is needed to mark it, one may regard this as the moment when Mach's spirit at long last found a resting place in the New World.

\section{THE VIENNA CIRCLE IN EXILE}

Between roughly 1940 and 1960 , the movement for a scientific philosophy in the United States flourished, pushed forward especially by the influx of the arrivals from Europe. The demons against which Mach and his contemporaries had battled were long since chased out of science, and the basic role of empiricism and logic in modern philosophy seemed secure. The main direction of the movement brought over from Europe was now identified most often by the slogans "Unity of Science" and "Unified Science," versions of the old terms Einheitswissenschaft and Gesamtauffassung that had animated the manifestos of 1911-1912 and 1929 as well as Carnap's Aufbau. These concepts in turn had roots in the perception-based phenomenalistic monism of Mach that had so appealed even to Carus. (Indeed, the Unity of Science Movement, as it now wanted to be known, came to refer to itself as "Monism free from Metaphysics.") It was Mach more than anyone else who had promised the elimination of the boundaries between the separate sciences; in his inaugural lecture in Vienna in 1895 he had put it picturesquely: "As the blood in nourishing the body separates into countless capillaries, only to be collected again and to meet in the heart, so in the science of the future all the rills of knowledge will gather more and more into a common and undivided stream." Frank called Mach "the spiritual ancestor of the Unity of Science Movement" and urged the adoption of Mach's program as that of "our Unity of Science Movement, of our Congresses, and of our Encyclopedia." 77 It was, so to speak, another way of standing Hegel on his head: unification not through metaphysics but through the elimination of metaphysics.

Various instrumentalities dedicated explicitly to such activities had been developing for some years in Europe and were now ready to deploy in America. Otto Neurath, the originator of a grand International Encyclopedia of Unified Science, and until his death in 1945 its central organizing champion, had planned the project at least as early as 1920 . The initial ambition for it was breathtaking: the archival collection of "Papers of the Unity of Science Movement" at the Joseph Regenstein Library of the University of Chicago indicates that two hundred encyclopedia volumes were planned, as well as ten supplemental volumes of a "Visual Thesaurus." The first collective "monograph," later to become the first of the nineteen "chapters" in the only two volumes of the encyclopedia that were actually published (under the title Foundations of the Unity of Science), came out

\footnotetext{
${ }^{76}$ Hahn and Schilpp, eds., Philosophy of Quine, p. 19. The list of impressive papers presented at the September 1939 conference is given in the Journal of Unified Sciences (previously Erkenntnis), 1939-1940, 8:369-371.

${ }^{77}$ Ernst Mach, Popular Scientific Lectures, 5th ed. (La Salle, Ill.: Open Court, 1943), p. 261; and Frank, Modern Science (cit. n. 42), p. 89. For a good, brief discussion of the various meanings of "unity of science" current in the 1930s see Herbert Feigl, "Unity of Science and Unitary Science," Journal of Unified Sciences (Erkenntnis), 1939-1940, 9:27-30.
} 
in 1938, containing essays by Bohr, Carnap, Dewey, Morris, Neurath, and Russell. The published volumes summarized the movement's status in the period between 1938 and the 1960 s as clearly as the Aufruf and the Vienna Circle manifesto, respectively, had done in their time, and they also explicitly invoked the ancestral link, with Neurath claiming in the first chapter of Volume 1 of the Encyclopedia to be "continuing the work of Ernst Mach."78

A second instrument of the movement was the Institute for the Unity of Science, founded by Frank and run under his presidency from 1947 on lines similar to those of the Ernst-Mach-Verein. Conducted under the aegis of the American Academy of Arts and Sciences in Boston (where Frank was elected a Fellow in 1943) rather than any university, the Institute used the Academy's Proceedings for some of its publications. Those links were not accidental, but were yet another example of the symbiosis between the Europeans' urge toward Einheitswissenschaft and similar American tendencies. As Frank explained later, the distinguished literary historian Howard Mumford Jones, on succeeding the astronomer Harlow Shapley as president of the Academy, had expressed the hope in his October 1944 inaugural address of overcoming "the fractation of knowledge" through the encouragement of the "pressures toward unity," for which the Academy, embracing members of all scholarly disciplines, seemed particularly well suited. A committee of the Academy to implement Jones's call soon agreed, calling for programs that would support the "synthesis of knowledge."79 In founding the Institute, Frank and his colleagues provided one of the more visible responses to this call. ${ }^{80}$

The energy and persuasiveness of the leaders of the movement were enormous. One example of the perspicacious expansion of their hold on the attention of American scholars was a letter of 29 October 1950, conveyed by Morris on behalf of the Institute to Robert K. Merton at Columbia University. The Institute said that it planned to issue bibliographies on key fields of interest; therefore, the letter continued, "we wish very much that you would do one on the sociology of science." So years before that field had begun to draw general attention in academe, the Institute had targeted it, as well as the obvious person to undertake a bibliography. ${ }^{81}$

As important for the Institute's impact as its publications-including separately

78 Otto Neurath, "Unified Science as Encyclopedic Integration," in Foundations of the Unity of Science, ed. Neurath et al. (cit. n. 62), Vol. 1 (Chicago: Univ. Chicago Press, 1955), pp. 1-27, on p. 14.

79 Philipp Frank, introductory remarks to the issue on "Contributions to the Analysis and Synthesis of Knowledge," Proceedings of the American Academy of Arts and Sciences, 1951, 80:5-8, on p. 6. President James B. Conant of Harvard added his welcome to this effort (pp. 9-13) and linked the "quest for unity in science" with his plans for the "general education" program in science for undergraduates.

${ }^{80}$ The Institute's charter of 31 July 1947, published in Synthese, 1947, 6:158-159, specified: “The purposes for which the corporation is formed are to encourage the integration of knowledge by scientific methods, to conduct research in the psychological and sociological backgrounds of science, to compile bibliographies and publish abstracts and other forms of literature with respect to the integration of scientific knowledge, to support the International Movement for the Unity of Science, and to serve as a center for the continuation of the publications of the Unity of Science Movement." The Institute's background and purpose are discussed in detail by Frank in the pages that follow, i.e., ibid., pp. 160-167.

${ }^{81}$ By March 1951 the bibliography had been prepared by Merton in collaboration with his former student Bernard Barber; it was published by Frank in the May 1952 issue of volume 80 of the Proceedings of the Academy. I thank Professor Merton for sharing copies of the correspondence. 
issued volumes by Frank and von Mises-were its regularly scheduled open meetings, usually held at the House of the Academy or in one of the universities' faculty clubs in the Boston area. These often resulted in vigorous and memorable discussions among attendees with varying degrees of allegiance to the movement; they included Henry Aiken, George D. Birkhoff, E. G. Boring, Bridgman, Karl Deutsch, Giorgio de Santillana, Frank, Roman Jakobson, Edwin C. Kemble, Gyorgy Kepes, Philippe Le Corbeiller, Wassily Leontieff, Hans Margenau and Ernst Nagel (as visitors), Talcott Parsons, Harlow Shapley, B. F. Skinner, S. S. Stevens, Lazlo Tisza, Norbert Wiener, and Quine-who described one of these meetings in his autobiography, adding that they too appeared to him "in the way of a Vienna Circle in exile." 82 Just as in the earlier meetings in Europe, advanced students and young instructors with sympathy for the aims of the group were encouraged to attend, perhaps in the hope that some of them would carry on the work in the future. Analogous meetings took place in Chicago, Los Angeles, Minnesota, Berkeley, and Princeton.

\section{AN ECOLOGICAL NICHE FOR A MOVEMENT}

There remains, finally, the need to return to a historical question with sociological overtones: What was it that made America, in roughly the middle third of this century, the most hospitable new home for the European descendants of nineteenth-century positivism? Although there were tragic victims of the persecution in Europe, and despite the well-known obstacles that scholars and scientists had to suffer initially, the number of members of the Vienna Circle and its associated groups in Prague, Berlin, Lwow, Warsaw, and elsewhere who eventually took up residence in the United States was substantial. ${ }^{83}$

The full answer is necessarily complex. In the first instance it includes, as previously indicated, the absence of predominant transcendental metaphysical philosophies and, on the contrary, the prior existence of analogous, native empiricist philosophical currents, of which the most recent was the "operationalism" ascribed to Bridgman and widely adopted by scientists after the 1927 publication of The Logic of Modern Physics ${ }^{84}$ But additional factors emerge from the records documenting the varied success of attempts by prominent refugeessuch as Frank, von Mises, Reichenbach, Tarski, and Zilsel-to find academic positions.

To summarize, when favorable, the outcomes were in most instances the result of several interacting forces at work in the United States. At each of the universities that eventually provided a place, there was at least one influential scholar who already knew of and respected the work of the candidate and undertook to labor on behalf of the cause. In this they were supported by recommendations

\footnotetext{
${ }^{82}$ Quine, Time of My Life (cit. n. 70), p. 219. I thank Professor P. R. Masani, now of the University of Pittsburgh, for supplementing my own memory of these meetings. As a graduate student he acted for a time as secretary of the group under Frank.

${ }^{83}$ For a sober assessment of the experience of immigrant scholars see Paul K. Hoch, "The Reception of Central European Refugee Physicists of the 1930s: USSR, UK, USA," Annals of Science, 1983, 40:217-246.

${ }^{84}$ A useful analysis is given by S. S. Schweber, "The Empiricist Temper Regnant: Theoretical Physics in the United States, 1920-1950," Historical Studies in the Physical and Biological Sciences, 1986, 17:55-98, with attention to Bridgman and Kemble.
} 
from distinguished scholars at other American institutions. The university system, even during those difficult post-Depression years, was flexible enough, and some administrators sufficiently ingenious, occasionally to permit the creation of a variety of temporary, part-time, or externally funded posts that would often lead to more permanent arrangements.

A large share of the credit goes also to "unofficial," private organizations specifically created to help with advice and funds, exemplifying the American talent for self-organization-such as the Institute of International Education in New York, inspired by Alvin Johnson and others, and its Emergency Committee in Aid of Displaced Foreign Scholars, each run by a remarkable roster of concerned Americans. The Rockefeller Foundation, chiefly through Warren Weaver, was intensely active in providing support. The correspondence among the immigrants themselves also shows that on the whole they were realistic about the need to accommodate initially to much reduced circumstances, and that they formed a chain along which useful information about possible positions was passed. The disgust among Americans created by the persecutions visited on the European victims of fascism and by its program of cultural destruction provided additional energy; this had prompted Bridgman's famous "Manifesto" announcing the closing of his laboratory to visitors from totalitarian states. ${ }^{85}$

But by far the most important factor was the American sponsors' feeling of welcome for the special expertise and general point of view brought by Continental scholars. To make this concrete by an exemplary case, one need only study the archival materials connected with the placement of one of the chief energizers of the European movement in its new home, Philipp Frank; similar cases could be presented for many others. ${ }^{86}$

By sheer luck, Frank and his wife Hania were spared the fate of so many after the rape of Czechoslovakia in 1939. They had come on a visit to America in 1938, and Frank was making a lecture tour of twenty universities where scholars were interested in his discussion of logical empiricism. One of these was Harvard, where his chief contact was Bridgman, who had been there since his undergraduate days in 1900-1904. He had corresponded with Frank's colleague at Prague, Carnap, since 1934, after Carnap had sent him The Unity of Science ${ }^{87}$ Bridgman, while expressing some reservation about the limits-in-principle of logic as a tool in every conceivable situation, had responded with enthusiasm: "In general I have taken great satisfaction in the writings of the Viennese Circle, including many of your own, as being more nearly akin to my own views than nearly any other analytical writing with which I am acquainted, and this last book of yours is no exception." (They continued to correspond for years, and it is significant that

\footnotetext{
${ }^{85}$ Published in Science, 1939, 89:179.

${ }^{86}$ Information and quotations in this section are taken from the following folders in the Harvard University Archives: Philipp Frank, Percy Bridgman, Edwin C. Kemble, and Harlow Shapley. I thank Clark Elliott and his staff for help with locating documents, and Kristin Peterson and Keith Anderton for much detective work in the archives.

${ }^{87}$ Originally a lecture delivered 1 Mar. 1931 under the auspices of the Ernst-Mach-Verein; expanded into an article, "Die physikalische Sprache als Universalsprache der Wissenschaft," in Erkenntnis, 1932, 2:432-465; and issued in English translation with an introduction by Max Black as The Unity of Science (London: Kegan Paul, Trench, Trübner, 1934). Carnap confided in a letter to von Mises, dated 19 Jan. 1934, that he was trying to find a way to spend a year at Harvard and Princeton to speak with scientists and philosophers there about common problems: Richard von Mises folder, Harvard University Archives.
} 
one topic was the nature of "pencil-and-paper operations," which were giving Bridgman considerable intellectual discomfort.)

Frank first contacted Bridgman in a letter of 25 February 1938, noting that he had "always firmly agreed with your operationalist view" and expressing interest in including Harvard in his forthcoming lecture tour so as to have "the opportunity of discussing with you and your friends and students the rôle of operationalism in modern physics." Frank included some of his reprints and a copy of Kausalgesetz in a French translation.

Bridgman's reply of 30 March 1938 - by which time Austria had welcomed the takeover by the Nazis, and Czechoslovakia was being threatened-is extremely revealing, for it casts light on similar situations at other universities that soon were to be offered refugee scholars. Bridgman wrote:

I was glad to get your letter and to know of your projected visit to this country next fall. . . . I read [the reprints and the book] with very great interest. It is naturally a source of gratification to me that we can agree on so many points. . . .

It will be a great pleasure to see you in Cambridge next fall and to talk things over with you. I am afraid you will not find Cambridge the center of activity with regard to the questions of interest to you which you apparently suppose. My work is done practically alone. I have no students [in philosophy of science] and have practically no contacts with members of the Department of Philosophy, and, in fact, most of them are not at all sympathetic with our point of view. The only young philosopher here whom I have particularly interested is Dr. Quine.

Bridgman's loneliness in philosophical matters-with which he struggled daily, even in his pioneering experiments in high-pressure physics-and Frank's evident excellence, made Bridgman interested in bringing Frank into the physics department when that idea was raised-a scenario to be played out many times, at Harvard and elsewhere. Thus the theoretical physicist Edwin C. Kemble, Bridgman's former student and now a philosophically close colleague at Harvard, had read an article by Frank on philosophy of science and wrote him, on 4 January 1939: "I feel perhaps a closer bond of kinship with you with respect to these matters than with anyone else with whom I have talked."

Frank came to visit Harvard in December 1938 and lectured on "Philosophical Interpretations and Misinterpretations of Quantum Theory" under the joint auspices of the Departments of Physics and Philosophy. The topic intersected with the continuing, real concerns of many scientists (including Kemble) and some philosophers (including D. C. Williams), concerns ranging from the status of unobservables to the nature of probability. This was just the kind of discussion that had been rare in the United States, while so prevalent on the Continent, for example in the interactions between Bohr, Einstein, Max Born, Erwin Schrödinger, Pauli, and Pascual Jordan with one another and with philosophers of science. Just as Mach had been found, in the words of H. A. Lorentz, to be essential "as a master and as a guide of their thoughts" through the thickets of late nineteenth- and early twentieth-century science, so Frank and his circle offered scholars in the United States guidance on more recent, persisting scientific and philosophical problems. Kemble diagnosed the needs in letters searching for funds with which to employ Frank, writing on 15 February 1939: "In recent years the borderland between physics and philosophy has come to be of increasing importance. It has become evident that clear ideas in physics cannot be had 
without the adoption of a correct, but far from naive philosophy. Theoretical physicists have become increasingly concerned with philosophy and philosophers have become increasingly influenced by the contributions of physicists." And he added: "Of all those with the training of the working physicist Frank is perhaps the most complete philosopher."

By spring 1939 Frank, now unable to return to Prague, was being considered for a one-year position at Harvard; he wrote to Bridgman from Chicago on 7 May that he looked forward to "the opportunity to collaborate with you and your department," to discuss "all the problems which belong to the so-called philosophical foundations of physics," to "help you to spread this spirit among the students of science," and to aid in the preparation of the "Unity of Science" congress at Harvard that Bridgman was to chair in September 1939. One recognizes echoes of the situation in which Frank had become so helpful to Ernst Mach himself, just thirty years earlier.

The relation between Bridgman and Frank was in fact quite symbiotic. Bridgman, with Kemble, spearheaded the presentation of the department's unanimous request (23 Mar. 1939) that Einstein's successor at Prague be given the temporary position of unpaid research associate in physics and philosophy (1939-1940); they settled for this modest proposal because the Harvard administration was reluctant to add to the six refugees recently accommodated in various parts of the university. Bridgman also wrote on Frank's behalf to the Harvard University Press on 19 January 1940, urging publication of a translation of Frank's collected essays on the philosophical foundations of physics, which he regarded as a "most important project," "a valuable service . . . to the American public," for Frank impressed Bridgman "as perhaps the soundest" of the Europeans in that field. With the energetic help of Harlow Shapley, who ran a sort of underground railway to all parts of the United States to place European scholars fleeing fascism ${ }^{88}$ and had contacts in the world of foundations, he also raised $\$ 2,000$ to cover the initial year of Frank's stay (which Frank had to supplement with the advance payment by the A. A. Knopf Publishing Company for a projected biography of Einstein).

Once he was established more firmly in Cambridge-on a multiyear, half-time lectureship funded by monies to be raised by Shapley-Frank in turn used to the full his lively mind and the persuasive skills he had honed for decades, in the service of propagating scientific philosophy. In addition to teaching and writing, he presided over the numerous and various activities of the Institute, as noted, in which Bridgman and many of his colleagues took part. His effect on students and other colleagues was memorable; Shapley summed it up in a note to Frank dated May 1962: "You [were] my ghost thinker."

So by the fall term of 1940 , the scene had changed dramatically from the lonely one depicted by Bridgman in his first letter to Frank two years earlier. Possibly the local readiness to give "modernism a chance" that had surfaced in the days of Josiah Royce, William James, and G. Santayana was now interacting with the effect of the war in Europe, breaking down old habits of isolation. At any rate,

${ }^{88}$ Bessie Zaban Jones, "To the Rescue of the Learned: The Asylum Fellowship Plan at Harvard, 1938-1940," Harvard Library Bulletin, 1984, 32:204-238. Shapley was intensely active also on behalf of von Mises, Tarski, Zilsel, Freundlich, and many others. 
when Feigl, at the University of Iowa since 1931, came back for a second Rockefeller Research Fellowship year at Harvard, he found the place transformed, with "fascinating regular discussions" in a group that included Frank, von Mises, Quine, Boring, Stevens, Bridgman, and I. A. Richards among the more active faculty members, as well as visitors such as Russell, Carnap, and Tarski. Like Quine, he observed: "There was a sort of revival of the Vienna Circle." ${ }^{89}$ More important, the experience encouraged Feigl and others to launch collaborative teamwork in philosophical research, which had not been a familiar practice in the United States. Thereby, and through critical responses for and against aspects of Continental empiricism, philosophy in America changed vastly during the next decades. Few major universities would choose to remain without representation in the philosophy of science, in contrast to the paucity tolerated in the early 1930s that we noted before.

But by the time of Frank's death in 1966, the movement as such had run its course. Starting in the mid 1950s, widely noted challenges to basic assumptions of logical empiricism had arisen out of the work of Quine and the late works of Wittgenstein, and also from two philosophically minded historians, Alexandre Koyré and Norwood Russell Hanson. The Institute and its activities had essentially ceased, and the fierce focus of the movement's early years had given way to a dispersal and penetration in a variety of other versions of contemporary thought. To its critics, one might have applied Einstein's dictum that they were unaware how much they had imbibed of the belief system that they were now berating. Or one may perhaps say with Lewis A. Coser that "the Circle died of its members' success. Most of those one-time outsiders became insiders in America, and hence found it impossible to maintain their separateness." 90 But the continuing importance attached to logic, to analysis of language, to cross-disciplinarity, and to the other hallmarks of the Old World schools that shared in the postMachian heritage is also a reminder of the role they played in helping the philosophy of science in the New World to rise to eminence.

What has also remained as one strain of contemporary philosophical thought is a commitment to the continued exploration of a science-based world view; it is characterized by a "critical attitude ... [as] the basic condition for a sensible approach to the practical problems of our day" and by the hope that unsolved problems of philosophy now "can be formulated and treated with a precision and clarity formerly unknown." These phrases, by the philosopher Joergen Joergensen, appear on the final page of the last chapter of the final volume of the movement's encyclopedia, Foundations of the Unity of Science. And in his very last sentence, that author gives his correct judgment of the value of the movement at its end: "They have not created a new philosophical system, which, indeed, would have been contrary to their highest intentions, but they have paved the way for a new and fruitful manner of philosophizing." 91 The new generation may have expected more. But it is appropriate to remember that Ernst Mach had expressed his own aims for scientific philosophy throughout in just such terms.

\footnotetext{
${ }^{89}$ Frank Lentricchia, "Philosophers of Modernism at Harvard, circa 1900," South Atlantic Quarterly, 1990, 89:787-832; and Feigl, "Wiener Kreis in America" (cit. n. 22), pp. 660-661.

${ }^{90}$ Lewis A. Coser, Refugee Scholars in America: Their Impact and Their Experiences (New Haven, Conn.: Yale Univ. Press, 1984), p. 306.

91 Joergensen, “Development of Logical Empiricism" (cit. n. 62), p. 932.
} 